\title{
Carcinoma-associated fucosylated antigens are markers of the epithelial state and can contribute to cell adhesion through CLEC17A (Prolectin)
}

\author{
Adrien Breiman ${ }^{1,2}$, María Dolores López Robles $^{1}$, Sophie de Carné Trécesson ${ }^{1}$, \\ Klara Echasserieau ${ }^{1,5}$, Karine Bernardeau ${ }^{1,5}$, Kurt Drickamer ${ }^{3}$, Anne Imberty ${ }^{4}$, \\ Sophie Barillé-Nion ${ }^{1}$, Frédéric Altare ${ }^{1}$, Jacques Le Pendu ${ }^{1}$ \\ ${ }^{1}$ Inserm U892, CNRS UMR6299, University of Nantes, 44007 Nantes, France \\ ${ }^{2}$ Nantes University Hospital, 44007 Nantes, France \\ ${ }^{3}$ Department of Life Sciences, Imperial College London, London SW7, UK \\ ${ }^{4}$ CERMAV-UPR 5301, CNRS, Université Grenoble Alpes, 38041 Grenoble, France \\ ${ }^{5}$ Recombinant Protein Core Facility of The University of Nantes, 44007 Nantes, France \\ Correspondence to: Adrien Breiman, e-mail: adrien.breiman@univ-nantes.fr \\ Jacques Le Pendu, e-mail: jacques.le-pendu@univ-nantes.fr \\ Keywords: fucose, lectins, epithelial to mesenchymal transition, lymph node metastasis
}

Received: July 31, 2015

Accepted: January 31, 2016

Published: February 18, 2016

\section{ABSTRACT}

Terminal fucosylated motifs of glycoproteins and glycolipid chains are often altered in cancer cells. We investigated the link between fucosylation changes and critical steps in cancer progression: epithelial-to-mesenchymal transition (EMT) and lymph node metastasis.

Using mammary cell lines, we demonstrate that during EMT, expression of some fucosylated antigens (e.g.: Lewis $Y$ ) is decreased as a result of repression of the fucosyltransferase genes FUT1 and FUT3. Moreover, we identify the fucose-binding bacterial lectin BC2L-C-Nt as a specific probe for the epithelial state.

Prolectin (CLEC17A), a human lectin found on lymph node B cells, shares ligand specificities with $\mathrm{BC2}$-C-Nt. It binds preferentially to epithelial rather than to mesenchymal cells, and microfluidic experiments showed that prolectin behaves as a cell adhesion molecule for epithelial cells. Comparison of paired primary tumors/ lymph node metastases revealed an increase of prolectin staining in metastasis and high FUT1 and FUT3 mRNA expression was associated with poor prognosis. Our data suggest that tumor cells invading the lymph nodes and expressing fucosylated motifs associated with the epithelial state could use prolectin as a colonization factor.

\section{INTRODUCTION}

Alterations of glycosylation are a hallmark of cancer. In particular, $\mathrm{N}$ - or O-glycans of proteins as well as glycolipids produced by cancer cells often carry an increased number of fucosylated motifs of the Lewis blood groups family $[1,2]$. Elevated levels of Lewis $\mathrm{Y}\left(\mathrm{Le}^{y}\right)$, Sialyl-Lewis A (SLe ${ }^{a}$ ) or Sialyl-Le ${ }^{x}\left(\mathrm{SLe}^{\mathrm{x}}\right)$ have been found in numerous types of carcinomas including colon or breast. Expression of such motifs has been shown to be associated with disturbance of the cell adhesion properties, increase in the migration capacity and invasion of ectopic tissues [3-5]. Although sialylated Lewis antigens have clearly been demonstrated to favor cancer cells extravasation through their interaction with selectins expressed on leukocytes or endothelial cells, functional consequences of neutral fucosylated antigens overexpression have remained elusive. Before entering the circulation, carcinoma cells go through a reversible cellular process called epithelialto-mesenchymal transition (EMT). EMT occurs during normal development and is also a hallmark of cancers. It consists in the loss of cell-cell contact and acquisition of mobility and invasiveness properties and has been involved in metastasis. EMT is characterized by a decrease in the expression of adhesion-related proteins (typically E-Cadherin) and increased expression level of various factors such as the cytoskeletal protein vimentin. The genetic reprogramming accompanying EMT is regulated 
by various transcription factors, belonging to 3 main families (Snail, Zeb and Twist) as well as by miRNAs, especially from the miR200 family, and can be triggered by cytokines such as TGF- $\beta$. Generation of cancer stem cells (CSC) has also been associated with EMT (reviewed in [6]). It is generally assumed that in order to colonize foreign tissue and establish metastasis, cells have to go through the reverse mechanism, mesenchymal-toepithelial transition (MET), however this process has not received as much attention as EMT.

As an alternative to the use of antibodies for the detection of abnormal glycosylations in cancer patients, proteins with carbohydrate-binding properties called lectins have been investigated. Although they were first identified in plants, lectins are present in all kinds of organisms from bacteria to humans. They are grouped in families according to their structural characteristics, chemical properties and ligand specificities [7]. Several lectins have been found to have relevance for cancer prognosis, including a lectin of the edible snail (Helix pomatia) and a lectin from the plant Maclura pomifera. Binding of those two lectins correlates with bad prognosis for breast and colon carcinomas [4, 8]. We recently identified the fungal lectin from Psathyrella velutina as a marker of truncated N-glycans present on lung cancer cells [9]. However use of lectins in the clinic has been limited until now, partly because of the difficulties associated with reliable production of lectins from plants or animals.

While lectins from plants, mushrooms or invertebrates have low affinity for human glycans, lectins from opportunistic bacteria, that have evolved to use human glycans as targets, could present stronger affinity and be used as specific markers. In the recent years, the $\alpha$-galactose (Gal) specific LecA from Pseudomonas aeruginosa, the $\alpha$-mannose (Man) specific Bc2L-A from Burkholderia cenocepacia and the $\alpha$-fucose (Fuc) specific RSL from Ralstonia solanacearum were produced in recombinant form and described [10-12]. Of special interest, the BC2L-C-Nt lectin from B. cenocepacia has been successfully produced in a recombinant manner. It folds in a trimeric TNF- $\alpha$-like structure and binds to $\alpha 2$ fucosylated blood group antigens such as $H$ type $1 / 3$ or $\mathrm{Le}^{\mathrm{y}}[13,14]$.

In this study we investigated the evolution and possible roles of fucosylated antigens expression during cancer progression. We used a panel of antibodies and lectins targeting Lewis antigens and found an association between expression of these antigens and the epithelial state, expression being lost in the mesenchymal state. We show that BC2L-C-Nt is a good tool to monitor these changes.

Since some mammalian lectins, belonging to the calcium-dependant family (C-type lectins), are able to bind Lewis fucosylated antigens, we considered the possibility that endogenous lectins could play a role in tissue colonization via interaction with tumor cells after they have engaged in MET. Indeed, C-type lectins play a role in processes such as cell-adhesion, leucocyte extravasation and pathogen recognition $[2,15]$. Our observation of a link between the epithelial state and expression of fucosylated glycans revealed using the BC2L-C-Nt bacterial lectin prompted us to look for potential endogenous lectins with similar glycan specificity. One intriguing member of this family is prolectin (encoded by the CLEC17A gene), which seems to be expressed mainly in dividing $B$ cells found in the germinal centers of secondary lymphoid organs. Prolectin is a type II membrane protein with an extracellular carbohydrate-recognition domain (CRD) closely resembling the CRD of the well-characterized dendritic cell lectin DCSIGN. However, the exact function of prolectin remains unknown [16]. Here we show that Prolectin can serve as a cell adhesion molecule for fucosylated epithelial cancer cells. We suggest a model presenting a possible role of prolectin in implantation of metastases in lymph nodes.

\section{RESULTS}

\section{Epithelial cells express more fucosylated antigens than mesenchymal cells}

EMT is characterized by a profound reprogramming of cellular gene expression. We thus sought to identify differences in histo-blood group antigens (HBGAs) displayed on the membranes of epithelial and mesenchymal cells (See Figure S1 for a diagram of HBGA synthesis pathways). We worked on breast cancer cell lines for which the EMT status has been well described. In addition, we used two EMT models based on the immortalized epithelial breast cell line MCF10A, from which mesenchymal counterparts had been derived by transfection with EMT-inducing factors, respectively the constitutively active oncogene $\mathrm{Kras}(\mathrm{v} 12)$ and the transcription factor SNAIL (SNAI1 gene). The control cell lines transfected with empty vectors and selected in parallel of MCF10A-KRAS(v12) and MCF10ASNAIL are referred to thereafter as MCF10A-LXSN and MCF10A-Puro ${ }^{R}$ respectively. We looked at the expression of several cancer-associated fucosylated antigens using flow cytometry and appropriate mouse mAbs (Figure 1A and 1B). All epithelial breast cell lines were found to express $\mathrm{Le}^{\mathrm{y}}$ as well as Le ${ }^{\mathrm{x}}$ and $\mathrm{H}$ type 3 antigens, except the non-cancerous cell lines MCF10A-LXSN/MCF10APuro $^{\mathrm{R}}$ that expressed only Le $\mathrm{C}^{\mathrm{y}}$. The slight difference in $\mathrm{Le}^{\mathrm{y}}$ expression profile between the two MCF10A control cell lines is probably due to clonal selection. Nonetheless, none of the neutral fucosylated antigens were detected on mesenchymal cell lines, including MCF10A-Kras(v12) and MCF10A-SNAIL. Some epithelial (MCF10A-LXSN, MCF10A-Puro ${ }^{\mathrm{R}}$, ZR-75.1) as well as mesenchymal cell lines (BT-549, MDA-MB-231, MCF10A-KRAS(v12), MCF10A-SNAIL) were positive for $\mathrm{SLe}^{\mathrm{x}}$ expression detected by the KM-93 antibody. However the HECA-452 
A

$\operatorname{Le}^{\mathrm{x}}$ (3E1) Le Le $^{\mathrm{y}}$ 12-4LE) H t3/4 (Mbr1) SLe ${ }^{\mathrm{x}}$ (KM-93; HECA-452) SLe ${ }^{\mathrm{a}}$ (19-9)

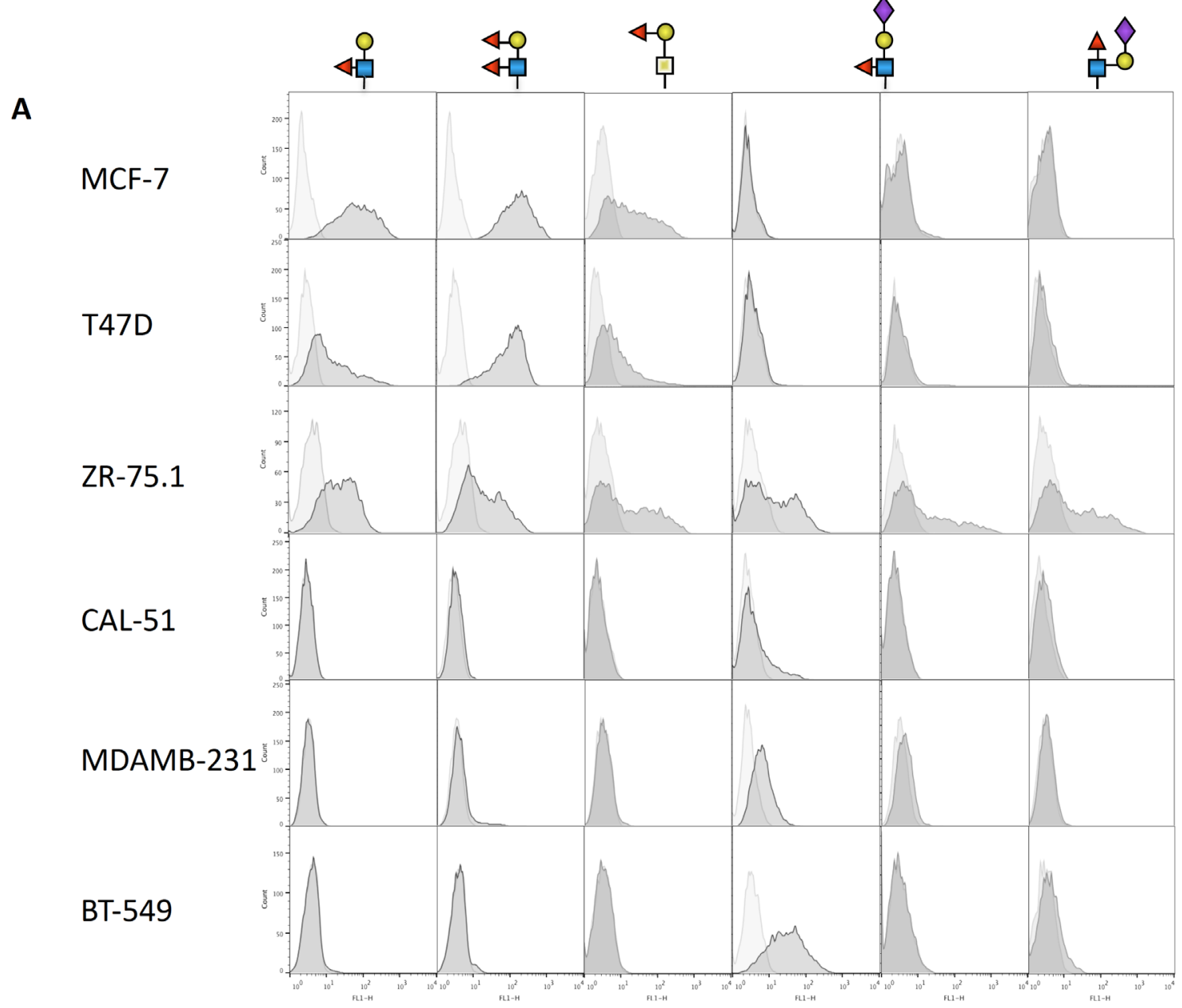

B

MCF10A-

LXSN

MCF10A-

Kras

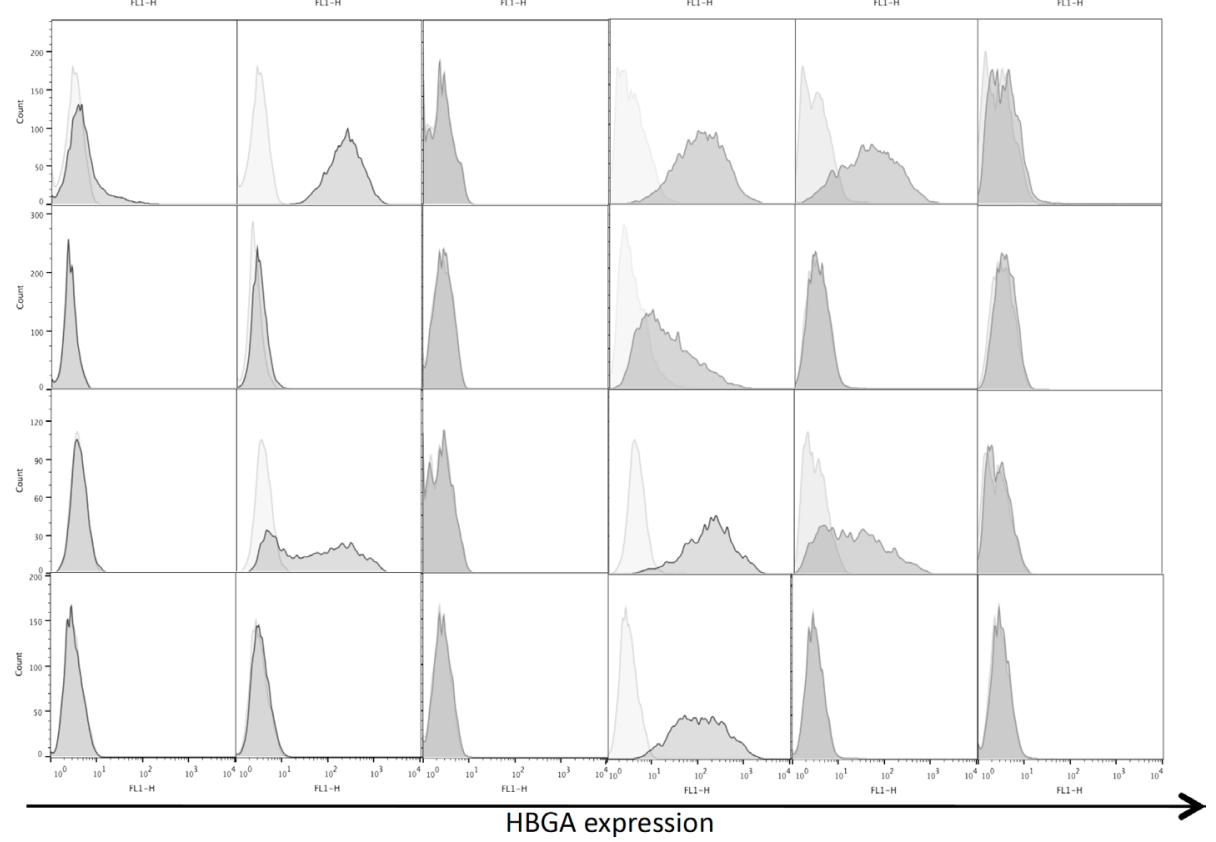

Figure 1: Expression of fucosylated antigens by mammary cell lines. Breast cell lines from tumor origin (A) or derived from the immortalized MCF10A cell line (B) were subjected to flow cytometry using various antibodies directed against fucosylated histoblood groups antigens, followed by an anti-mouse-FITC secondary antibody. The horizontal axis represents mean fluorescence intensity (MFI) while cell count is indicated on the vertical axis. Structures of the glycan epitopes recognized by each antibody are shown below the antibody description. 
antibody that is more fucose dependent than the KM-93 [17] only stained epithelial cell lines (ZR75.1, MCF10ALXSN and MCF10A-Puro ${ }^{\mathrm{R}}$ ). SLe ${ }^{\mathrm{a}}$ was poorly expressed if at all on the breast cell lines tested except for ZR75.1.

\section{BC2L-C-Nt preferentially binds to epithelial breast cell lines}

We then tested fucose-specific bacterial lectins: BC2LC-Nt from $B$. cenocepacia and the broadly fucose-specific RSL from $R$. solanacearum. As a comparison, we also tested the well-characterized $\alpha 2$-fucose-specific plant lectin Ulex europeaus agglutinin-I(UEA-I). Lectins used are listed in Table S1

We found that the BC2L-C-Nt staining was clearly higher on cell lines characterized as epithelial as compared to those characterized as mesenchymal (Figure 2). Interestingly, other fucose-specific lectins such as UEA-I and RSL did not distinguish between the two phenotypes as clearly as BC2L-C-Nt (Figure S2A). In order to determine if lectins with other types of specificity could present a similar or complementary binding profiles compared to BC2L-C-Nt, we tested BC2L-A, and LecA, specific for mannose and galactose respectively and neither of these lectins showed a clear distinction between epithelial and mesenchymal cells (Figure S2B).

\section{Epithelial cells express higher levels of FUT1 and FUT3 than mesenchymal cells}

In order to confirm the epithelial preference of BC2L-C-Nt, we treated MCF10A cells with TGF-ß, which was able to induce a partial EMT as shown by: (1) morphological change (Figure 3A), (2) vimentin induction as shown by immunofluorescence (Figure $3 \mathrm{~B}$ ) and flow cytometry (Figure S3) and (3C) a reduction of E-cadherin mRNA expression and an increase of SNAIL and SLUG mRNA expression (See Figure 3C). We performed FACS analysis with anti-Le ${ }^{y}$ and anti-SLe ${ }^{\mathrm{x}}$ on TGF- $\beta$ treated cell. Although we could not observe a decrease in the $12-4 \mathrm{LE}$ staining, KM-93 and HECA-45 labeling were reduced by respectively 40 and $70 \%$ (Figure S3). We also found a small but significant reduction in BC2L-C-Nt staining in cells treated with TGF- $\beta$ (Figure 3D). Reversion to the epithelial phenotype (MET) could be partially achieved by withdrawing TGF- $\beta$ (as shown by a reduction of vimentin expression as well as by increase of E-Cadherin and decrease of SNAIL and SLUG mRNAs levels, See Figure 3B and Figure 3C) and this was accompanied by an increase in BC2L-C-Nt staining (Figure 3D). We then investigated whether the difference in fucosylated antigen expression between epithelial and mesenchymal cell lines reflected a difference in fucosyltransferase gene expression. We first analyzed available transcriptomic data from a panel of 51 breast cancer cell lines [18]. Breast cell lines have been classified in categories called luminal, corresponding to the luminal $\mathrm{A} / \mathrm{B}$ tumour histologic type and associated with a pronounced epithelial phenotype, Basal A, corresponding to the Basal tumor type and Basal B, characterized by a high expression of mesenchymal specific genes and CSC markers [19, 20]. In humans, 8 fucosyltransferases genes can contribute to the synthesis of fucosylated antigens: FUT1-7 and FUT9. FUT1 and FUT2 encode $\alpha$ 1-2-fucosyltransferases, whereas the others encode $\alpha 1-3 / 4$-fucosyltransferases [21]. We observed that FUT5, 6, 7 and 9 were weakly or very weakly expressed in the breast cell lines. FUT1 and FUT3 were significantly more expressed in luminal and Basal A cell lines than in the Basal B cell lines, whereas no significant difference was observed for FUT2 and FUT4 (Figure S4). We therefore used the MCF10A model to check if there is a relationship between FUT1/ FUT3 expression and EMT. We performed qRT-PCR using FUT1- and FUT3-specific probes on untreated or TGF-ß-treated MCF10A-LXSN cells, MCF10AKras(v12) cells and MCF10A-Puro ${ }^{\mathrm{R}} / \mathrm{MCF} 10 \mathrm{~A}-\mathrm{SNAIL}$ cells. We observed that FUT3 expression was markedly reduced when EMT was induced by TGF- $\beta$ treatment. In addition, FUT3 expression was at least partially restored upon TGF- 3 withdrawal. Moreover FUT3 was absent in cells overexpressing Kras(v12) or SNAIL. The FUT3 gene expression pattern was strikingly similar to that of the $\mathrm{CDH} 1$ gene encoding E-cadherin, but in contrast with that of SNAI1 (SNAIL) and SNAI2 (SLUG) (Figure 3C and Figure S5). The association between FUT1 and EMT was less pronounced (Figure 3C), although its expression was suppressed by SNAIL overexpression (Figure S5). The above results prompted us to look at the promoter sequences of the FUT1 and FUT3 genes to see if there were binding motifs for the EMT inducing transcription factors. We found several E2-boxes (CAGGTG or CACCTG), which are classical SNAIL-binding motifs, similar to those that can be found in the E-cadherin promoter. Moreover, bipartite elements (C)AGGTG/ $\mathrm{CACCT}(\mathrm{G})$ are binding motifs for $\mathrm{ZEB} 1 / 2$, which are also EMT-inducing transcription factors [22, 23] (Figure S6A). Analysis of the transcriptome of the 51 breast cancer cell lines showed an inverse relationship between expression of FUT1/3 and of SNAI2 and ZEB1/2 (Figure S6B).

The above results from surface fucosylation staining and analysis of fucosyltransferase expression suggest that there is a relationship between surface expression of neutral $\alpha 1,2$ and $\alpha 1,3 / 4$ fucosylated glycans, and EMT/MET.

\section{The human C-type lectin prolectin has similar glycan specificity as BC2L-C-Nt and efficiently binds human cell lines and tumor tissues}

The association between the epithelial state and fucosylated glycans that we demonstrated above could result in interaction with some endogenous lectin(s) in the metastatic microenvironment that could favor tumor cells implantation. We identified in databases the fucose-specific 
lectin CLEC17A (prolectin) as a good candidate because it recognizes non-sialylated Lewis-type ligands and has the interesting property of being expressed mainly in secondary lymphoid organs, a very common site for tumor metastasis.

Prolectin is a type II transmembrane C-type lectin with an extracellular CRD and a cytoplasmic tail
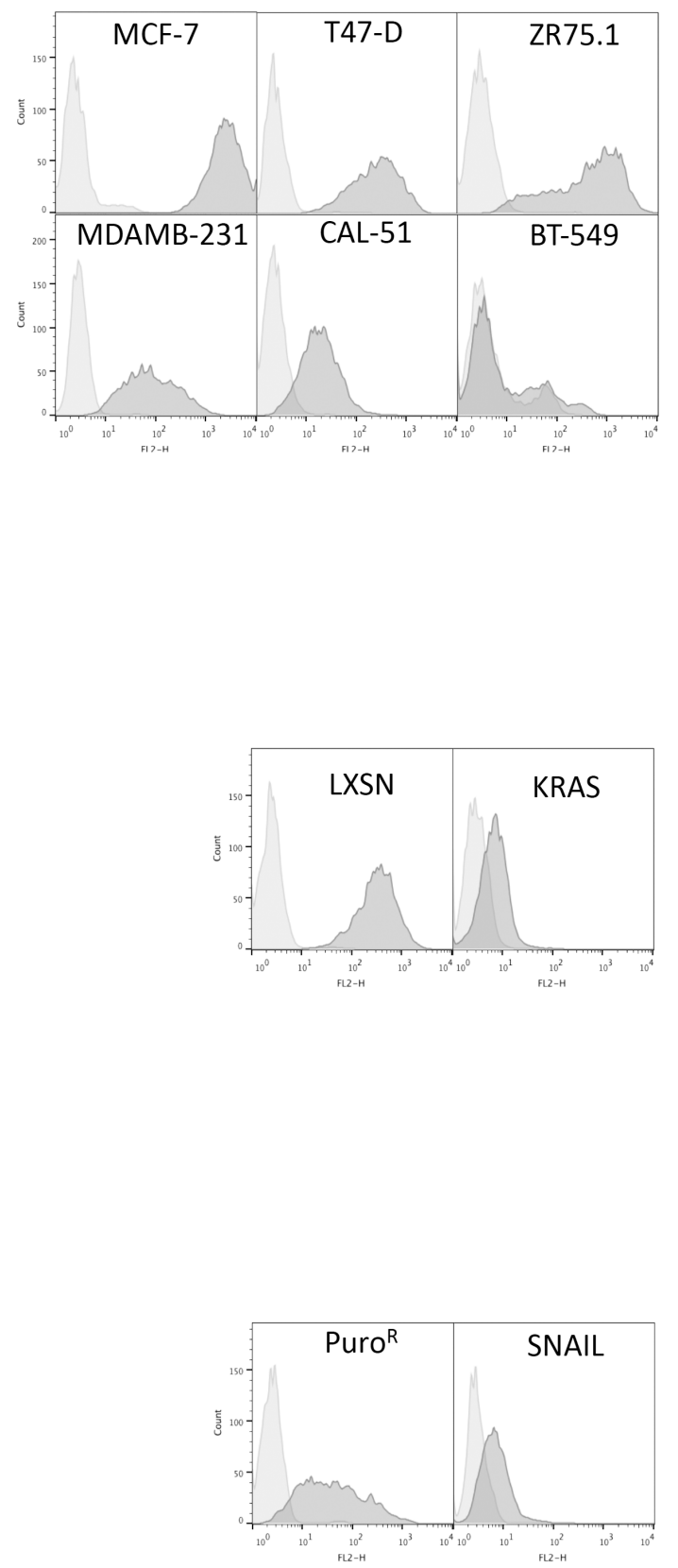

containing SH2 and SH3 signaling domains (Figure 4A). It has been shown to bind both poly-mannosylated ligands and neutral fucosylated ligands on the glycan microarray from the Consortium for Functional Glycomics [16].

The prolectin CRD was produced in bacterial cells, purified by gel filtration, biotinylated in vitro and used in

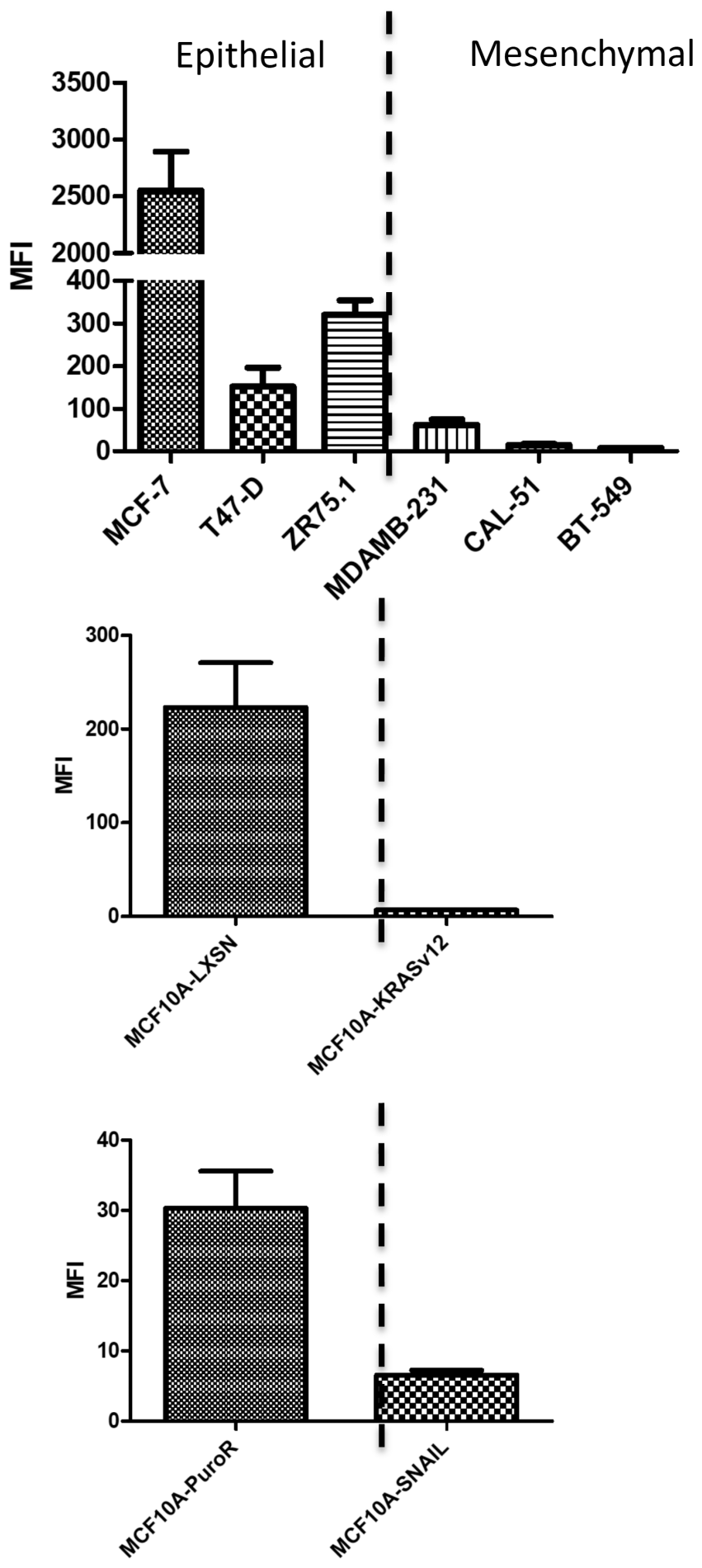

Figure 2: The fucose binding lectin BC2L-C-Nt stains epithelial cells rather than mesenchymal cells. Breast cell lines were stained with biotinylated lectins BC2L-C-Nt followed by PE-conjugated streptavidin and analyzed by flow cytometry. Representative flow cytometry histograms as well as a histogram of the mean and SEM of Mean fluorescence intensities (MFI) for three independent experiments are presented. 
A

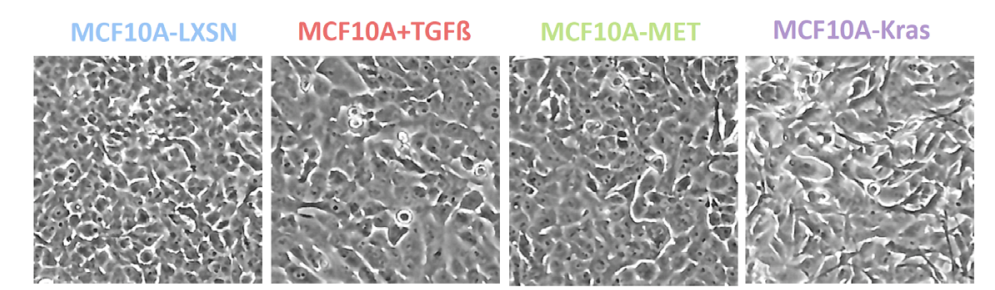

B
C
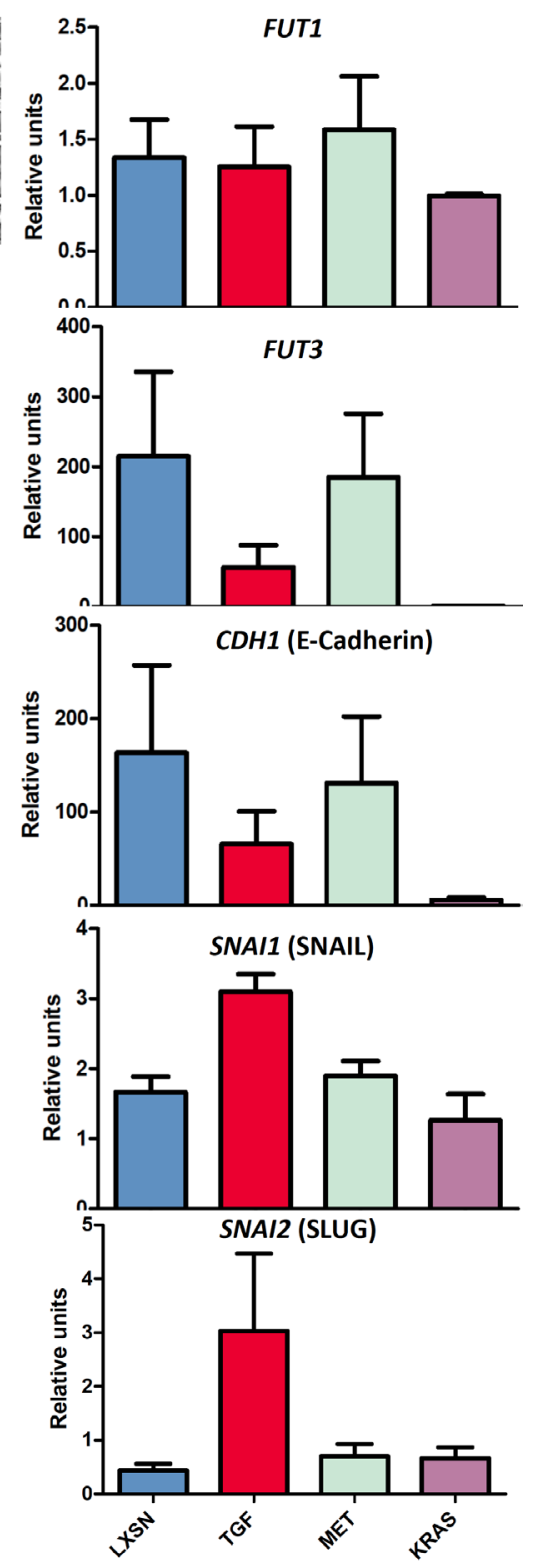

Figure 3: BC2L-C-Nt staining decreases following EMT induction in parallel with fucosyltransferase expression. MCF10A-LXSN cells were passaged in the presence of $10 \mathrm{ng} / \mathrm{ml} \mathrm{TGF- \beta 1} \mathrm{e-Bioscience} \mathrm{to} \mathrm{induce} \mathrm{EMT} \mathrm{(MCF10A+TGF-} \beta$ ). The cells were then grown a further 4 days in the absence of TGF- $\beta$ to induce a MET (MCF10A-MET). (A) Morphological appearance of the cells. (B) MCF10A-LXSN epithelial cells were treated with either 0,5 $\mu \mathrm{M}$ A83-01 (MCF10A-LXSN) or $5 \mathrm{ng} / \mathrm{ml}$ TGF- $\beta 1 \mathrm{R} \& \mathrm{D}$ (MCF10A+TGF) during four days. TGF- $\beta$ was then withdrawn and cells were grown four more days in presence of 0,5 $\mu \mathrm{M}$ A83-01 (MCF10A-MET). Cells were analyzed by immunofluorescence using anti-E-cadherin and anti-Vimentin antibodies followed respectively by a Dylight 488-conjugated and a Rhodamine-conjugated secondary antibody. Nuclei were stained with Hoechst. Pictures were taken with a Nikon confocal microscope at a x60 magnification (C) Total RNAs were extracted from the different cell lines and cDNAs were synthesized using oligo-dT and subjected to qPCR analysis with FUT1, FUT3 and GAPDH specific primers and probes. FUT1 and FUT3 expression levels are presented relative to GAPDH expression. The PCR on CDH1, SNAI1 and SNAI2 was performed using specific primers and SYBrGreen and results are presented relatively to ß-actin expression. Data shown are the mean and SEM of three independent experiments. (D) Binding of BC2L-C-Nt to cells analyzed by flow cytometry. The results are the means and SEM of the MFI of BC2L-C-Nt staining for four independent experiments including the three used in Figure 3C. Statistical significance has been assessed with 2-tailed paired $t$-tests between the indicated data sets. 
a tetrameric complex with streptavidin as described in Material and Methods. We then tested prolectin binding on a range of fucosylated ligands of the HBGA series. As lectin binding to carbohydrate is quite dependent on the underlying molecule, we used two different kinds of carriers: polyacrylamide beads (PAA) or human serum albumine (HSA).

When we compared prolectin and BC2L-C-Nt binding on a range of neutral HBGAs, the two lectins showed quite similar but distinct binding profiles. In particular, $\mathrm{Le}^{\mathrm{y}}$ was one of the most efficiently recognized ligands for both of these lectins (Figure 4B; detailed formulas of the oligosaccharides used are given in Table S3). We went on to test prolectin binding to a panel of established tumor cell lines from various histological origins: breast, colon, ovary, prostate, which were all positive for $\mathrm{Le}^{\mathrm{x}}$ and $\mathrm{Le}^{\mathrm{y}}$ (Table S4). Prolectin was found to bind to all the tumor cell lines. As expected, this interaction is mediated by the sugar-binding site, as it was abolished by pre-incubation of the lectin with an excess of fucose monosaccharide (Figure 4C).

We also tested prolectin binding on the MCF10A cell lines and found that the fluorescence level on MCF10A-LXSN and MCF10A-Puro ${ }^{\mathrm{R}}$ cells was markedly higher than on the Kras(v12)- and SNAIL-transfected counterparts, showing that, like BC2L-C-Nt (but to a lesser extent), prolectin displays a preference for epithelial cells (Figure 4D).

We tested prolectin binding to human tumor tissue sections from breast $(N=40)$, colon $(N=39)$, lung $(N=39)$ and uterine cervix $(N=50)$. Prolectin stained $80-95 \%$ of the tumors ( $\geq 5 \%$ of positive cancer cells). The percentage of cancer cells stained was quite variable (between 5 and 100\%) for breast and uterine tumors. Most lung and colon tumors presented $\geq 80 \%$ positive cells. We also noticed in some tumor samples a high number of infiltrating leucocytes that were strongly stained, although lymphoid tissues were mostly negative (Figure S7). Paired adjacent healthy tissue was generally much less stained that the corresponding tumor and the labeled structures were mostly the outer epithelial layers, preferentially on the apical side (Figure 4E). Again, this binding of prolectin was glycan dependent, as it was inhibited in the presence of EDTA, which chelates the $\mathrm{Ca}^{2+}$ of the CRD as well as in the presence of fucose (Figure 4E).

\section{Prolectin can behave as an adhesion molecule for cells expressing fucosylated ligands}

Since prolectin is a membrane C-type lectin, an interesting hypothesis was that it could mediate interactions with cells expressing the appropriate ligands, as selectins do with $\mathrm{SLe}^{\mathrm{x}}$ expressing cells. We decided to investigate this possibility using the BioFlux microfluidic system. This system makes it possible to generate a tightly controlled shear flow pressure inside microfluidic channels, which can be coated with cells or proteins. As prolectin is expressed on B cells in the lymph nodes, the interaction with tumor cells is not expected to happen in the blood stream (in contrast to the interaction with selectins), however we thought that performing our experiments under a low shear flow $\left(0,05-0.1 \mathrm{Dyn} / \mathrm{cm}^{2}\right)$ would correspond to the situation of motile cells reaching lymphoid organ cells and would additionally give higher stringency for the study of cell-prolectin interaction than using static conditions.

We coated the microchannels with prolectin CRD/ streptavidin tetramers and injected Chinese hamster ovary $(\mathrm{CHO})$ cells transfected with one or several glycosyltransferases so as to make them express various fucosylated ligands ( $\mathrm{H}$ type $2, \mathrm{Le}^{\mathrm{a}}, \mathrm{Le}^{\mathrm{b}}$; Figure S8). A few normal $\mathrm{CHO}$ cells bound to the prolectin-coated surface, however twice as many of the CHO-H (FUT1) and 3-times more of the $\mathrm{CHO}-\mathrm{Le}^{\mathrm{a}}$ and $\mathrm{CHO}-\mathrm{Le}^{\mathrm{b}}$ were bound, consistent with the prolectin staining of the cells as analyzed by flow cytometry (Figure 5A). Interestingly, after less than $30 \mathrm{mn}$ of binding, the CHO-Le ${ }^{\mathrm{a}}$ cells already displayed an elongated shape. We thus compared $\mathrm{CHO}$ and $\mathrm{CHO}-\mathrm{Le}^{\mathrm{a}}$ binding on Lab-tek chamber slides coated with either prolectin or poly-lysine. After $2 \mathrm{~h}$, bound $\mathrm{CHO}$ cells had a round shape regardless of which coating was used. CHO-Le ${ }^{\text {a }}$ cells were mostly round or ovoid on poly-lysine, but most were elongated when bound on the prolectin coating (Figure S9).

We next tested the binding of human cancer cell lines on the prolectin coating under flow conditions. To this end, we injected the cells in a buffer containing $25 \mathrm{mM}$ of either fucose or galactose. We performed 5 independent experiments with the prostate cancer cell line DU-145, which has good characteristics for this kind of experiments, as the trypsinized cells are round and mostly well isolated. Despite important variations in the absolute number of bound cells, there were always more bound cells in presence of galactose, which should not affect prolectin, compared to the presence of fucose, which blocks prolectin. This pattern was also observed with the other cancer cell lines MCF-7, OVCAR-3 and HT-29 (Figure 5B). The affinity of prolectin galactose is weak but not inexistent (see [16]), which means that the efficiency of adhesion of those two cell lines to the prolectin coating might have been somewhat underestimated in our experimental design. We also found that bound cells were those expressing the highest level of prolectin ligands (Figure S10).

Binding of MCF10A-LXSN and MCF10AKras(v12) cells to a prolectin coating was also compared using the BioFlux system. Flow cytometry analysis was performed in parallel. As already mentioned, prolectin stained MCF10A-LXSN cells more strongly than MCF10A-Kras(v12) cells. An even more important difference was found when looking at adhesion of cells to the prolectin layer under the shear flow conditions, since 
A

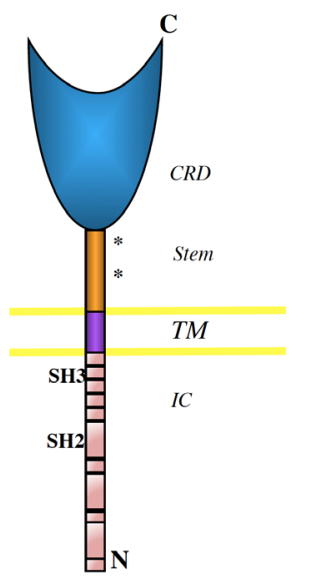

\section{C}

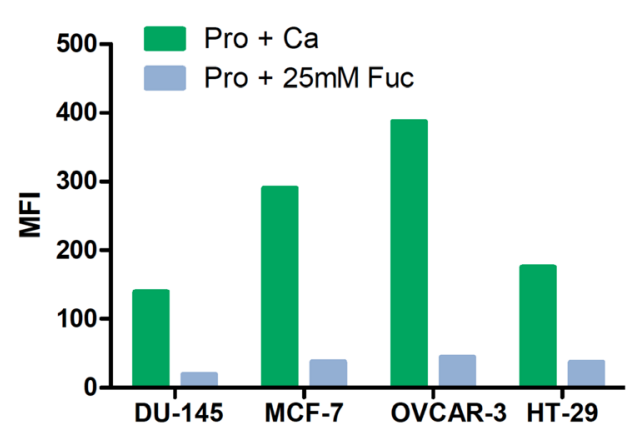

E
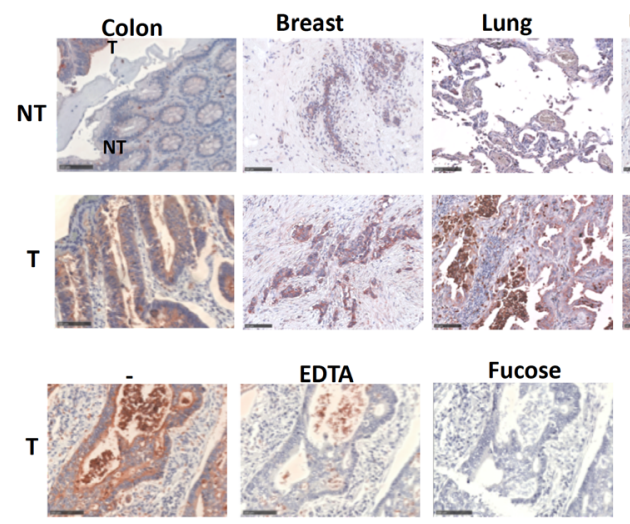

B

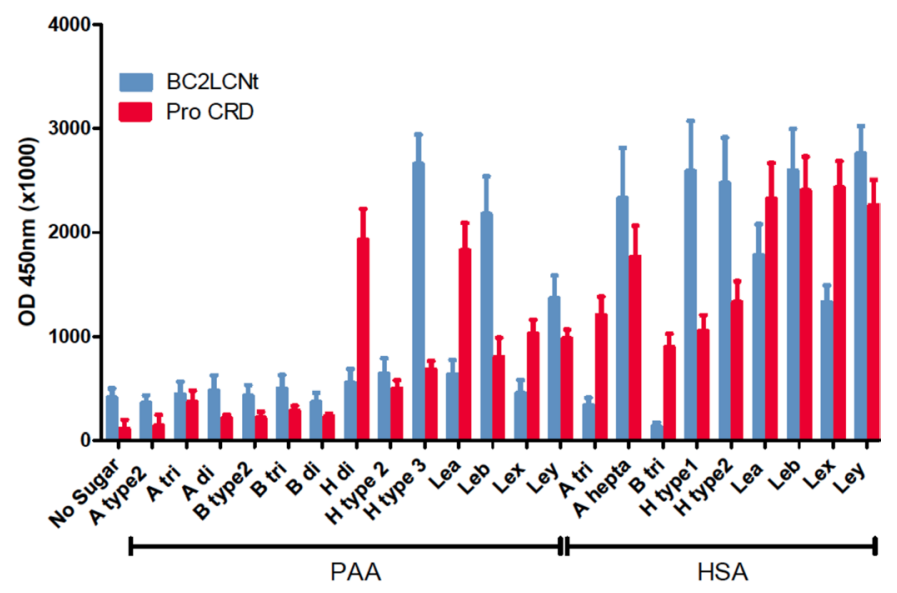

D 
only the epithelial MCF10A-LXSN cells, but not their Kras(v12) mesenchymal counterparts, were able to adhere (Figure 5C). Prolectin recognizes fucosylated ligands, but also high mannose glycans [18]. Thus, in order to get better insight into which type of sugar ligands were involved, we treated cells with glycosylation inhibitors. First, we used 2-fluoro-fucose (2F-Fuc), a competitive inhibitor of all the cellular fucosyltransferases. The effect of $2 \mathrm{~F}$-Fuc treatment on the expression of the fucosylated markers was controlled using BC2L-C-Nter. The labeling of treated cells was nearly completely abolished (Figure S11). 2F-Fuc treatment markedly decreased prolectin binding to MCF10A-LXSN cells while it did not have any effect on the lower binding to MCF10A-Kras(v12) cells, strongly suggesting that the difference in staining by prolectin between the two cell lines is essentially due to the presence of fucose residues on MCF10A-LXSN cells. Moreover, 2F-Fuc treatment suppressed adhesion of MCF10A-LXSN cells to the prolectin coating, showing that fucose residues are primarily responsible for the binding (Figure 5C). To further delineate the respective role of fucose versus mannose recognition by prolectin, we also treated the cells with kifunensine (KFN), an $\alpha$-mannosidase I inhibitor that blocks maturation of N-glycan chains maturation and consequently increases expression of high mannose chains at the cell surface. The increase of mannose presentation by KFN was controlled by staining with the mannosespecific lectin BC2L-A (Figure S11). As expected, KFN treatment increased prolectin binding on both cell types. However, KFN did not change the efficiency of adhesion of these cells to the prolectin layer (Figure 5C). This result confirmed that fucosylated ligands play a major role in prolectin binding to epithelial cells, while mannose residues constitute the remaining ligands on mesenchymal cells. However, mannose recognition did not appear to significantly contribute to adhesion of prolectin, which was mainly fucose-dependent.

Since a coating of the prolectin CRD was able to mediate adhesion of cells under flow, we sought to determine whether adhesion would also happen in a cellcell interaction context with the native protein. For these experiments, we used RAT6 rat fibroblasts transduced with a retrovirus containing the whole CTLY11 (CLEC17A) prolectin cDNA. About half of the RAT6-CTLY11 cells were positive for surface prolectin expression whereas no prolectin was detected on the cells transduced with the empty vector (RAT6-Neo) (Figure 5D).

A monolayer of DU-145 cells was grown in the BioFlux channel and RAT6-Neo or RAT6-CTLY11 cells were injected. We compared the speed of movement of RAT6-Neo and RAT6-CTLY11 cells by capturing short videos and measuring the distance covered by the fibroblasts on image sequences corresponding to 1 second. We found that prolectin-expressing fibroblasts passed through the channel more slowly than the RAT6-Neo cells. We then injected RAT6-CTLY11 suspended in a buffer containing either galactose or fucose. Cells were found to move significantly more slowly in the presence of galactose than in the presence of fucose (Figure 5D). Similar results were obtained on a monolayer of MCF-7 cells (Figure S12). Although involvement of other fucosespecific lectins cannot be formally excluded, these results suggest that the presence of prolectin at the cell surface can induce rolling onto a layer of tumor cells.

\section{Higher levels of prolectin ligands are associated with lymph node metastasis and elevated FUT1/3 expression correlates with a worse prognosis}

Since endogenous prolectin is expressed in lymph nodes, it has the possibility to interact with infiltrating tumor cells. In this case, it would be expected that the tumor cells retained in the lymph node are those that express more prolectin ligands. We therefore compared staining of paired primary breast tumors and lymph node metastasis with prolectin CRD. A score was established corresponding to the estimated percentage of labeled tumor cells, modulated by a color intensity index. The score was found to be significantly higher for the metastatic tissue than for the primary tumor tissue (Figure 6A).

We next wondered whether there could be some relationship between levels of FUT1 and/or FUT3 expression and the disease progression. We used the meta analysis tool bc-GenExMiner which compiles transcriptomic data from breast cancer studies (http:// bcgenex.centregauducheau.fr/; [24]). Forest prognostic analysis was performed on the whole set of patients (irrespective of their nodal or estrogen receptor status) and the first pejorative event considered was represented by any relapse or death (referred to as "any event"). High-level expression (i.e. above the median expression of the gene) of both FUT1 and FUT3 was correlated to a bad prognosis with hazard ratios of $1.12(P=0.0243)$ and $1.14(P=0.00966)$ respectively (Figure 6B an Figure S13A). No such correlation was found for other fucosyltransferases. Similar results were obtained with the KM plotter online platform (http://kmplot.com/analysis/ index.php? $\mathrm{p}=$ service\&cancer=breast; [25]; See Figure S13B)

Collectively, these results suggest that prolectin could help implantation of metastasis in the lymph nodes through binding of fucosylated ligands on incoming tumor cells.

\section{DISCUSSION}

In this study, we have shown that fucosylated motifs such as $\mathrm{Le}^{\mathrm{y}}$ tend to disappear during the course of EMT and that this change reflects repression of the FUT1 and FUT3 enzymes expression in mesenchymal cells. Consistent with this change in glycosylation, we found that the bacterial fucose-binding lectin BC2L-CNt differentially stains epithelial and mesenchymal cells. This property was not shared by the well-characterized 
A
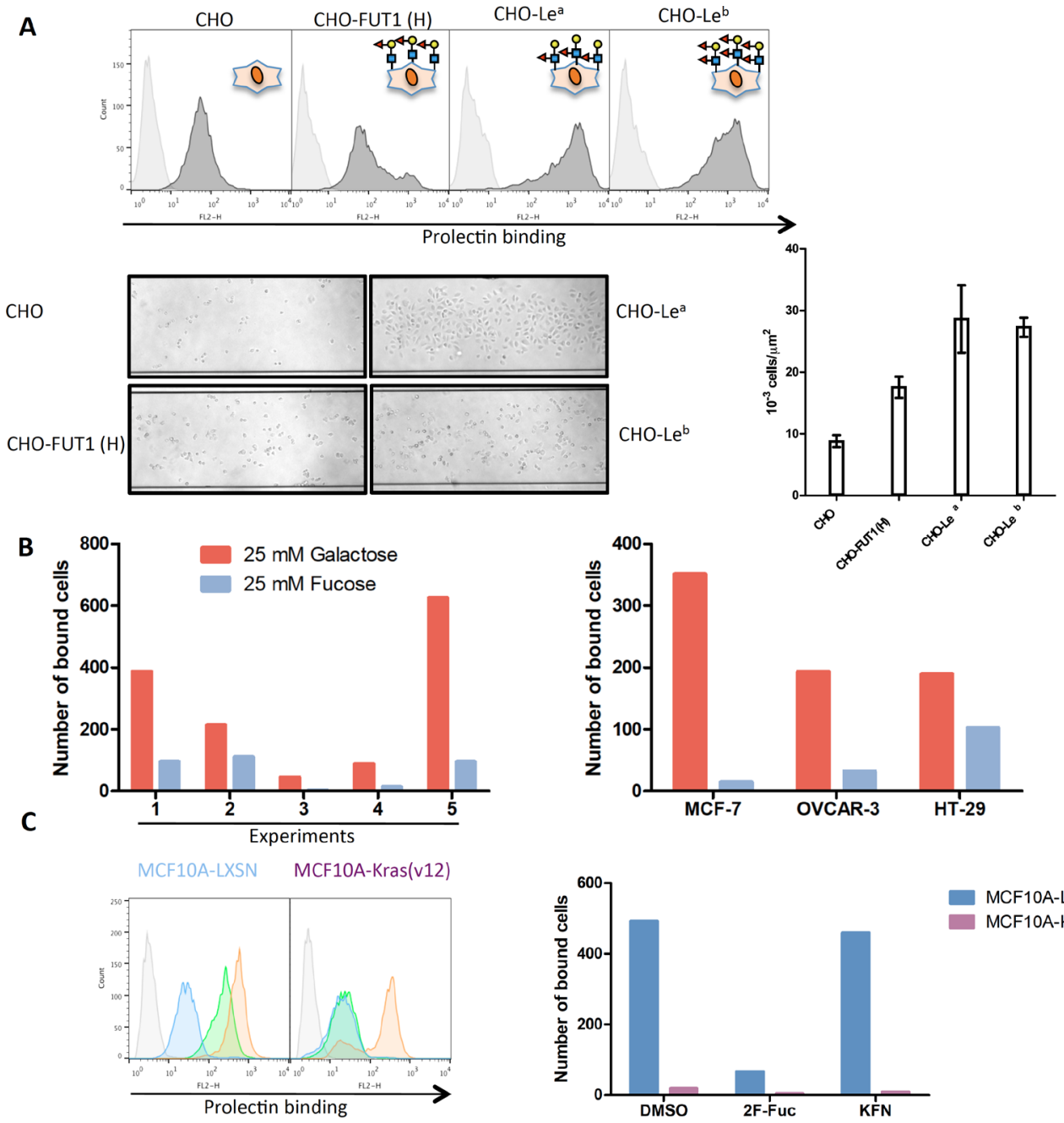

D
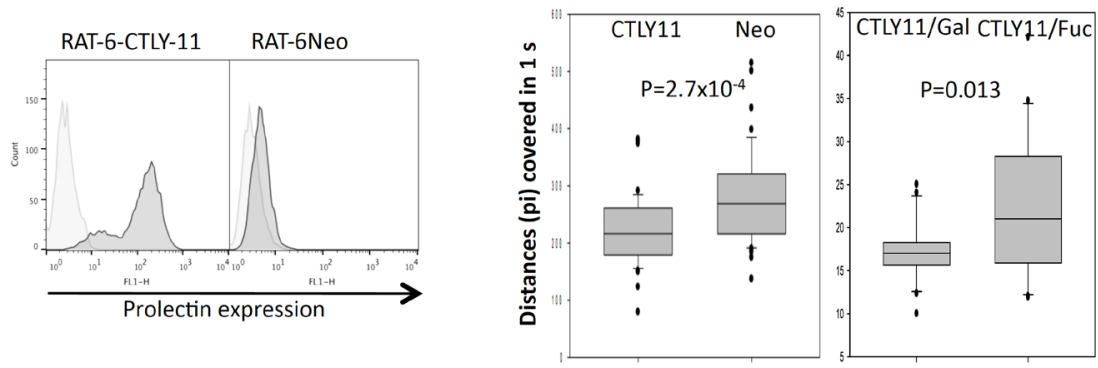

Figure 5: Prolectin acts as a cell adhesion molecule. (A) Expression of fucosylated markers on normal $\mathrm{CHO}$ cells or $\mathrm{CHO}$ cells engineered to express fucosylated antigens tested by flow cytometry. Cells were introduced in the channels of a BioFlux microfluidic system coated with prolectin/streptavidin tetramers under a pressure of $0.1 \mathrm{Dyn} / \mathrm{cm}^{2}$. Unbound cells were washed away and pictures of the attached cells were taken at 10x magnification with a Leica DMI 6000B microscope. Bound cells were counted on three different segments along the channels and the mean cell densities and SEM are represented on the histogram. (B) DU-145 cells were introduced in the channels under a pressure of $0.1 \mathrm{Dyn} / \mathrm{cm}^{2}$ and in presence or $25 \mathrm{mM}$ D-galactose or L-fucose. Unbound cells were washed away and pictures of the attached cells were taken. Bound cells were counted in the whole channels. The results of five independent experiments are shown. Due to the high variation between experiments, the results are shown separately. Similar experiments were performed with the other tumor cell lines MCF-7, OVCAR-3 and HT-29. (C) MCF10A-LXSN and MCF10A-Kras(v12) cells were treated with dimethyl sulfoxide (DMSO, green), $5 \mu \mathrm{M}$ kifunensin (orange), or $400 \mu \mathrm{M} 2 \mathrm{~F}$-fucose (blue) during four days and stained with prolectin by flow cytometry as described above. Control cells and cells treated with the inhibitors were injected into prolectin-coated BioFlux channels. Unbound cells were washed away and pictures of the attached cells were taken. Bound cells were counted in the whole channels. (D) Prolectin expression was tested on Rat6-Neo and Rat6-CTLY11 fibroblasts by flow cytometry. Percentages of "positive" cells are indicated. Rat6-Neo and Rat6-CTLY11 or Rat6-CTLY11 in the presence of $25 \mathrm{mM}$ galactose or fucose were injected in BioFlux channels covered with a layer of DU-145 cells under a pressure of $0.05 \mathrm{Dyn} / \mathrm{cm}^{2}$. Films of 1 minute (600 pictures) were acquired on a Leica DMI 6000B microscope using the Metamorph software. Chronophotographic images, corresponding to 10 pictures segments of the films, were constructed using the FiJi software and distances covered by individual cells were measured. Student tests were performed to assess statistical significance. 
fucose-binding lectin UEA-I. In vitro, BC2L-C-Nt binds efficiently to $H$ type $1 / 3$, but poorly to $H$ type 2 [13]. This means that if type 2 rather than type 1 structures are expressed, which seems to be the case in the breast cell lines, $\mathrm{BC} 2 \mathrm{~L}-\mathrm{C}-\mathrm{Nt}$ will poorly bind in conditions where the level of $\alpha 1,3 / 4$ fucosylation is low. In contrast, UEA-I has a strong preference for $\mathrm{H}$ type 2 and will still bind, providing the cells have $\alpha 1,2$ fucosyltransferase activity. This probably explains why BC2L-C-Nt display higher specificity than UEA-I for epithelial versus mesenchymal cells. We propose that $\mathrm{BC} 2 \mathrm{~L}-\mathrm{C}-\mathrm{Nt}$ could be a good tool to sort out cells with an epithelial phenotype in a mixed

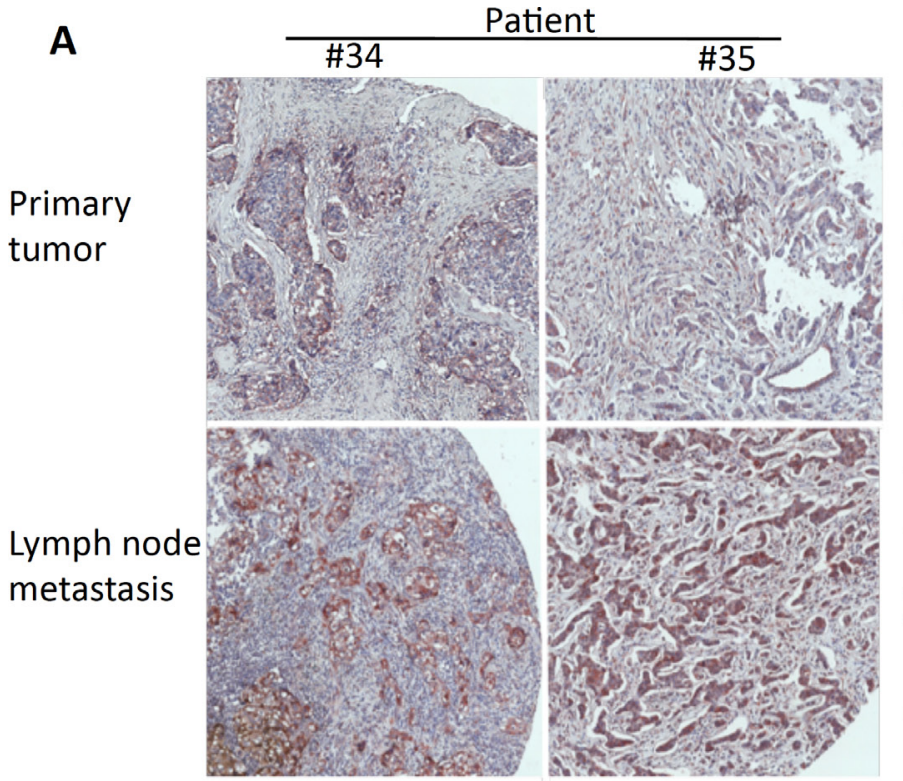

B

FUT1

Kaplan-Meier survival estimates for pool

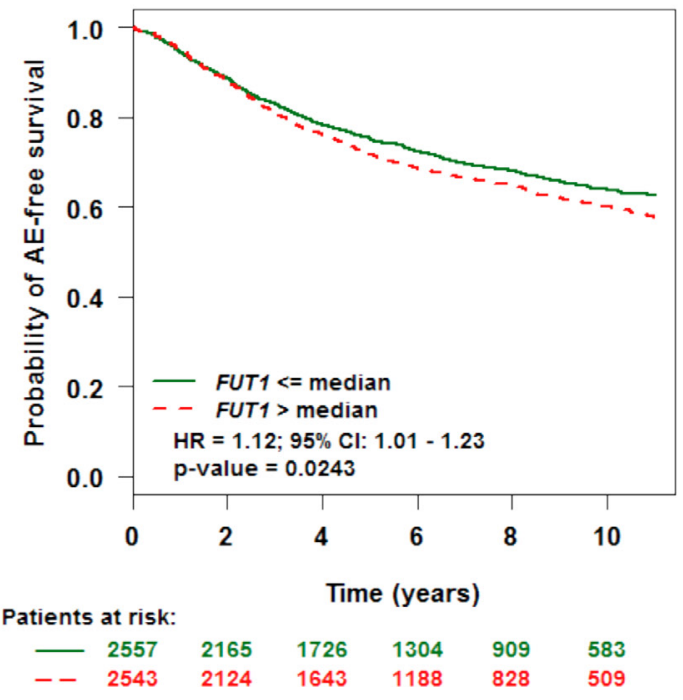

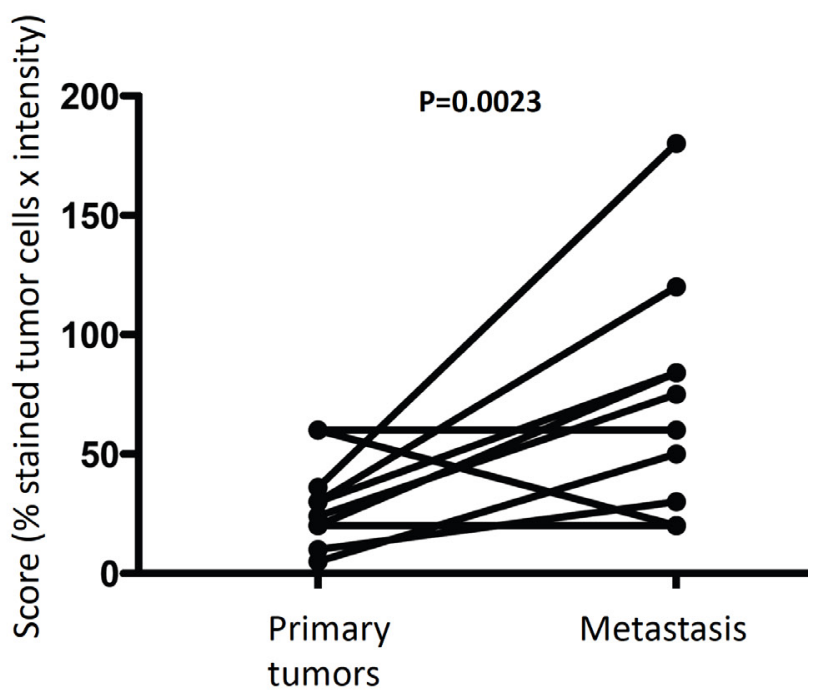

FUT3

Kaplan-Meier survival estimates for pool

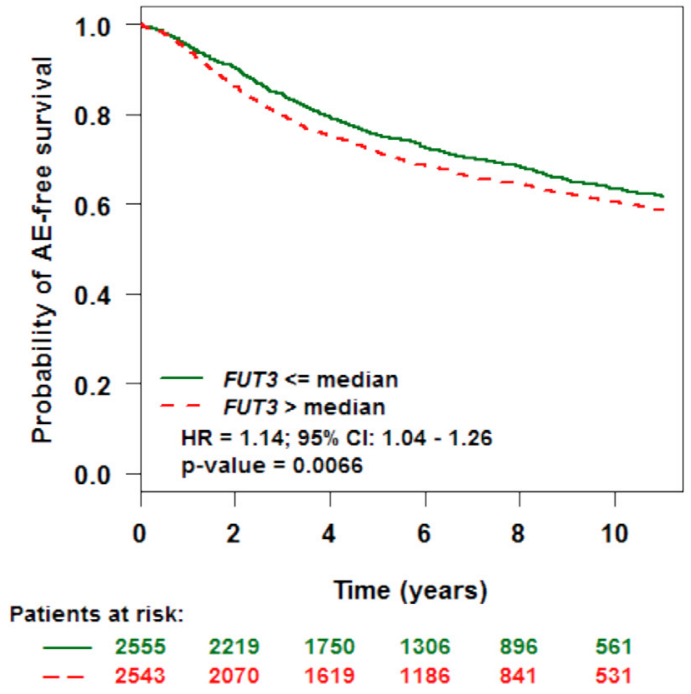

Figure 6: Associations between prolectin ligand expression, lymph node metastasis and clinical prognosis. (A) The level of staining by the prolectin CRD was quantified on the 10 primary tumor/lymph node metastasis pairs from the breast TMA of Figure 4 . A global score representing the proportion of stained tumor cells corrected by the staining intensity was established. Prolectin staining intensity was scored as,$++/++,+/+++$ and $++/+++$ and percentage of positive tumor cells was adjusted using coefficients of $1,1.2,1.5$, 1.5 and 2 respectively. Pictures of two of the pairs are shown as examples. Statistical significance has been determined using a 2-tailed Wilcoxon test. (B) Computational analysis of breast cancer patient data were performed using the online platform bc genexminer (http:// bcgenex.centregauducheau.fr). FUT1 and FUT3 expression are grouped into high and low level expression by comparison with the median expression of each gene. Analysis shown was done on all the patients irrespective of their nodal or estrogen receptor status (AE: Any Event; HR: Hazard Ratio). 
population. In the past few years, a great deal of effort has been put in the development of various systems for sorting circulating cancer cells in the bloodstream (see [26] for a review). Considering the vast heterogeneity of cancer cells, it is essential to target different markers to achieve the best sensitivity and specificity. In this context, BC2L$\mathrm{C}-\mathrm{Nt}$ could be used in combination with other antibodies or lectins to improve sorting of the epithelial cancer cells from blood. BC2L-C-Nt has been recently described as a good probe for embryonic stem cells (ES) or induced pluripotent stem cells (iPS) identification [27, 28]. Interestingly, those types of pluripotent stem cells tend to express epithelial markers such as epithelial cell adhesion molecule (EPCAM) or E-Cadherin, which is in contrast with the so-called cancer stem cells that are associated with a mesenchymal phenotype [29]. It is thus possible that $\mathrm{BC} 2 \mathrm{~L}-\mathrm{C}-\mathrm{Nt}$ could be used to distinguish between different types of stem cells.

We observed that both FUT1 and FUT3 were downregulated in the course of EMT. Potential binding sites for SNAIL and ZEB transcription factors are present in the FUT1 and FUT3 promoters similar to those contained in the E-cadherin promoter, which is known to be repressed by proteins from these families [22, 23, 30, 31]. FUT3 seemed to be more sensitive to the EMT-related repression as it was drastically down-regulated both by expression of Kras(v12) and of SNAIL, whereas FUT1 was much more sensitive to SNAIL than to Kras(v12). TGF-ß treatment also decreased FUT3 expression but not that of FUT1. Very recent data show that Kras induces EMT in breast cells via SLUG (SNAI2) rather than SNAIL (SNAI1) or ZEB [32], which might explain the difference for FUT1 repression between MCF10A-Kras or MCF10A cells treated with TGF- $B$ on the one hand, and MCF10A-SNAIL on the other hand.

TGF- $\beta$ treatment was poorly efficient at inducing EMT in our hands. Using MCF10A cells, Zhang et al have shown that TGF-ß-induced EMT is a two-step process, going through a SNAIL-driven intermediary stage before reaching the complete mesenchymal state [33]. For reasons difficult to explain, we could only achieve a partial transition. However, we think our results with cancer cell lines and with the two MCF10A-based EMT models clearly demonstrate that fucosylation is down regulated in breast mesenchymal cells.

Interestingly, Sakuma et al. have shown in colon cancer cells that following induction of EMT by EGF, FUT2 expression is repressed via down-regulation of the colon-specific transcription factor CDX-2. However, in contrast to our results, the level of FUT3 expression was up-regulated rather than down-regulated due to increased recruitment of c-Myc to the FUT3 promoter [34]. It is possible that in the context of colon cells, a higher level of activating signals makes it possible to bypass the EMTdriven repression of FUT3. In a very recent study, Tan et al. have used a murine mammary cell line (NMuMG) with or without TGF- $\beta$ treatment to extensively analyze the glycosylation changes occurring during EMT. In a lectin microarray, they found reduced staining by the Fuc $(\alpha 1,3)$-specific lectin from Lotus tetragonolobus on the TGF- $\beta$ treated cells. Transcriptome analysis also showed reduced expression of several FUTs [35].

Mesenchymal cells have a higher invasive potential than epithelial ones. Cancer cells invasiveness is often linked to increased expression of selectin ligands (SLe ${ }^{\mathrm{x}}$ and SLe ${ }^{\mathrm{a}}$ ) that allow extravasation and foreign tissues colonization [36-40]. It has been shown that increased expression of FUT1 in HT-29/M3 increases $\alpha 2$-fucosylation of the type 2 (Galß1-4GlcNAc-R) disaccharide which, by competing with sialylation, leads to a decrease of the synthesis of $\mathrm{SLe}^{\mathrm{x}}$ and hence of the invasive and metastatic capacities of the cells [41]. In the study of Sakuma et al. [34], EMTassociated down-regulation of FUT2 and induction of FUT3 expression leads to increased levels of $\mathrm{SLe}^{\mathrm{x}}$ on the cell surface. Thus, it seems contradictory that in breast cancer cell lines, induction of EMT leads to repression of FUT3 expression and suppression of both neutral and sialylated Lewis antigens presentation. As $\mathrm{SLe}^{\mathrm{x}}$ was detected on mesenchymal cells such as BT-549, MCF10A-KRAS or MCF10A-SNAIL with the KM-93 antibody only but not with the HECA-452 antibody, it is likely that this is due to the cross-reactivity of KM-93 with sialylated lactosamine [17], suggesting that the decrease of FUT3 expression also leads to a decrease of $\mathrm{SLe}^{\mathrm{x}}$ presentation. Previous reports have indeed suggested that expression of $\mathrm{SLe}^{\mathrm{x}}$ and E-Selectin ligands was dependant on FUT3/FUT6 expression in breast tumors and cell lines [3, 42].

Functional significance of $\mathrm{Le}^{\mathrm{y}}$ overexpression by epithelial cancer cell is less well understood. Hotta et al. reported that $\mathrm{Le}^{\mathrm{y}}$ was deleted in the invasive front of oral squamous tumors and that expression of FUT1 and $\mathrm{Le}^{\mathrm{y}}$ in squamous cancer cell lines is associated with reduced proliferation and invasiveness [43]. However, in oral cancers, Le $^{y}$ has also been suggested to promote cell migration via stabilization of EGFR and downstream signaling [44]. Interestingly, a recent study shows that overexpression of FUT1 in bladder cancer cell lines increases integrin $\beta 1$ activity and enhances cell adhesion [45]. Further studies are needed to better understand the regulation and functional consequences of glycosylation changes during EMT.

We also showed that the C-type lectin prolectin, expressed in lymph nodes, was a fucose-dependent epithelial cell adhesion molecule. Prolectin also reacts with polymannosylated ligands and therefore does not distinguish between epithelial and mesenchymal cells as well as BC2L-C-Nt when used as a probe for flow cytometry. Nevertheless, we showed that fucosylated cells could adhere to a layer of prolectin in low flow conditions. Mesenchymal or "de-fucosylated" epithelial cells show dramatically reduced adhesion to prolectin. Rat fibroblasts stably expressing Prolectin also showed reduced velocities when placed under flow on a tumor 
cell monolayer. We could not observe actual adhesion of the prolectin-expressing cells on tumor cells in those conditions. It might be argued that rat fibroblasts are not the most appropriate model to study cell-cell adhesion to human tumor cells. It is also possible that the density of prolectin at the fibroblast surface is not sufficient to allow firm adhesion such as what occurs on the surface coated with prolectin CRD. It would be interesting in the future to obtain a B-cell line with or without prolectin to perform the fluidic experiments in more physiological conditions. In addition, as prolectin has a cytoplasmic tail containing $\mathrm{SH} 2$ and SH3 domains [16], it would be interesting to determine if interaction of prolectin expressing B-cells with tumor cells triggers some signaling pathways in the B-cells and the consequences that such signaling could have in terms of B-cell activation and functional properties.

Although the exact role of prolectin interaction with tumor cells is not clear yet, we provide indirect evidence that it could be involved in metastasis implantation in lymph nodes. Firstly, meta-analysis of breast cancer data shows that high levels of expression of FUT1 and FUT3 are associated with a bad prognosis. A higher expression of genes coding those fucosyltransferases can lead to a higher presentation of fucosylated ligands for prolectin at the tumor cell surface. Secondly, when probing with the prolectin CRD, we observed more intense staining of lymph node metastasis than of the matching primary tumors, suggesting that tumor cells that have a greater ability to interact with prolectin, might initiate metastasis development more efficiently in the lymph nodes. It has to be noticed that the role of tumor cell interaction with prolectin-expressing cells will be difficult to directly test in vivo, since rodents do not possess an ortholog for the CLEC17A gene.

We propose the model illustrated in Figure 7. In a carcinoma overexpressing fucosylated motifs such as $\mathrm{Le}^{\mathrm{y}}$ and SLe ${ }^{\mathrm{x}}$, some cells will go through an EMT, allowing them to detach from their original tissue and migrate to blood or lymphatic vessels. During EMT, Le ${ }^{y}$ and $\mathrm{SLe}^{\mathrm{x}}$

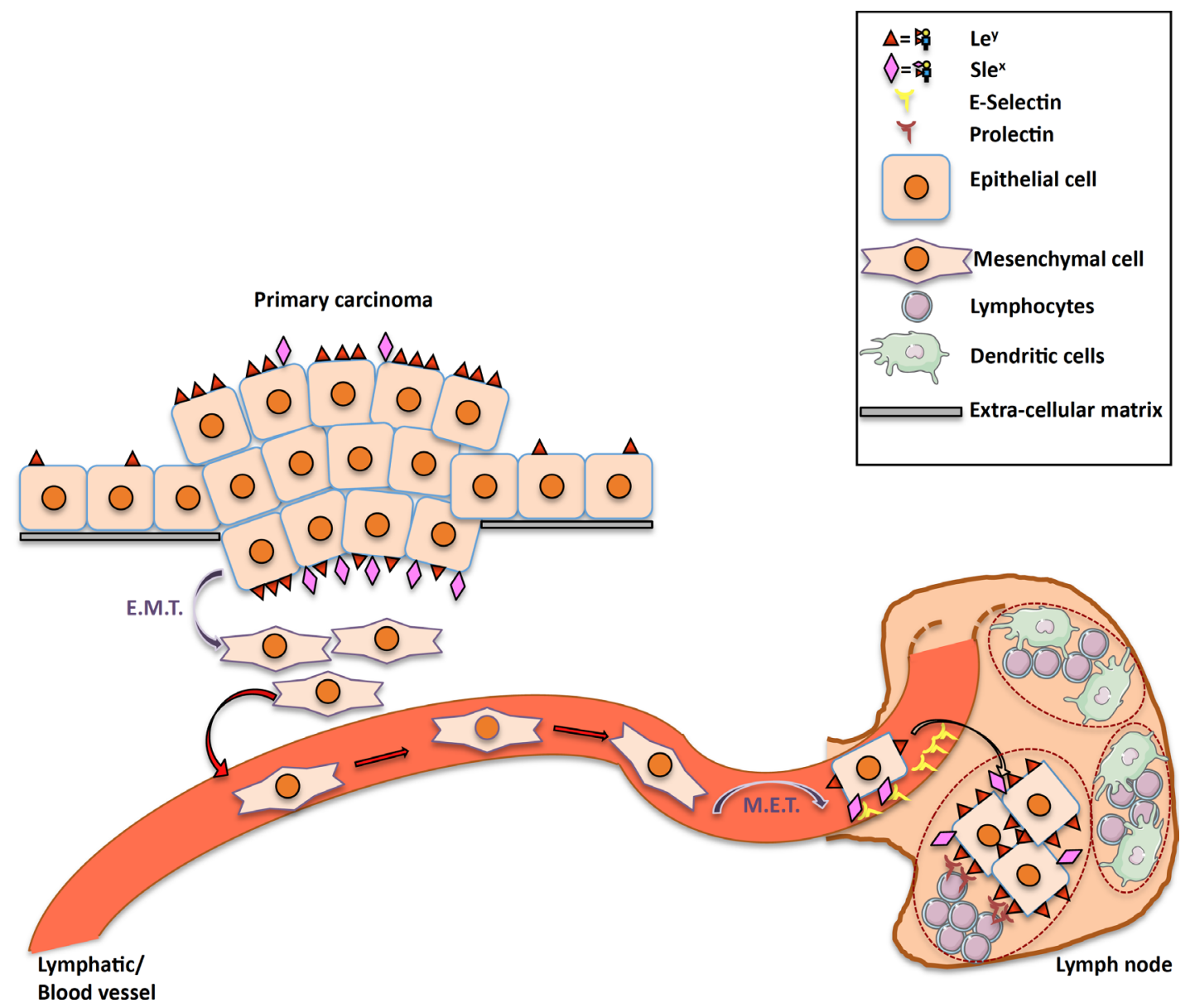

Figure 7: Proposed model for the roles of prolectin and fucosylated antigens in lymph node metastasis. Increased expression of both neutral fucosylated glycan motifs such as Le ${ }^{y}$ and charged fucosylated structures such SLe ${ }^{a / x}$ is observed on primary tumor cells as compared to their normal counterpart. These fucosylated markers, are lost during EMT that allows tumor cells to migrate and pass into the blood or lymphatic streams. When reaching the target lymph node, these cells use the selectin ligands for extravasation and undergo MET. The latter step will be accompanied by re-expression of fucosylated ligands through FUT1 and FUT3 expression, thereby allowing binding to prolectin that will contribute to the settlement of the metastatic cells in the lymph node. 
disappear from the cell surface. By a process of MET, tumor cells will re-express fucoslylated ligands. The SLe ${ }^{\mathrm{x}}$ motifs allow cancer cells to interact with the endothelium of the lymph node afferent vessels and to exit from the blood/lymph stream. Upon entrance into the lymph node, neutral fucosylated ligands allow carcinoma cells to interact with germinal center B cells expressing prolectin, which will help them to settle in the lymph node.

Reticker-Flynn and Bhatia have just described a somewhat similar involvement of a lectin-carbohydrate interaction in the establishment of the metastatic niche. In their case, overexpression of the Thomsen-Friedenreich antigen (Galß1-3GalNAc) by lung adenocarcinoma metastatic cells allowed them to interact with galectin-3 expressed on pro-tumorigenic leucocytes [46].

Interestingly, during the preparation of this manuscript, two studies have challenged the idea that EMT would be required for metastasis $[47,48]$. This means that epithelial cancer cells could actually leave the primary tumor, migrate to the lymph node and interact with prolectin without the need of going through EMT/MET cycles.

In conclusion, our study provides a direct link between the mesenchymal state and repression of some fucosyltransferases expression. We also describe the bacterial lectin BC2L-C-Nt as a new tool to monitor EMT and the human $\mathrm{C}$-type lectin prolectin as a potential new player in lymph node metastasis.

\section{MATERIALS AND METHODS}

\section{Cell culture}

MCF-7, T47-D, BT-549, DU-145 and OVCAR3 cells (obtained from ATCC) were grown in RPMI 1640 GIBCO (Life Technologies) supplemented with 10\% Fetal Calf Serum (FCS) GIBCO. The CHO cell lines were grown in RPMI-10\% FCS supplemented with $10 \mu \mathrm{g} / \mathrm{ml}$ each of adenosine, thymidine and 2-deoxyadenosine (Sigma). CHO-H cells were obtained by stable transfection of CHO cells with the rabbit FUT1 enzyme as described in [49]. CHO-Le ${ }^{\mathrm{a}}$ and $\mathrm{CHO}-\mathrm{Le}^{\mathrm{b}}$ were a kind gift from Jan Holgersson [50]. CAL-51 (obtained from DSZM), MDA-MB-231, ZR-75.1, HT-29 (obtained from ATCC), RAT6-Neo and RAT6-CTLY11 were grown in DMEM containing 4,5 g/l glucose and supplemented with $5 \%$ (CAL51, MDA-MB-231) or 10\% FCS. $100 \mu \mathrm{g} /$ $\mathrm{ml}$ of $\mathrm{G} 418$ (neomycin) at $100 \mu \mathrm{g} / \mathrm{ml}$ was added to the RAT6 fibroblasts medium to maintain prolectin expression [16]. MCF10A-Kras(v12) and the empty vector control MCF10A-LXSN are a kind gift from Dr Ben Ho Park [51]. MCF10A-SNAIL cells and their corresponding MCF10APuro $^{R}$ controls were obtained from Dr Stéphane Ansieau [52]. MCF10A cell lines were grown in DMEM:HamF12 (1:1) GIBCO supplemented with 5\% Horse Serum GIBCO, 0,5 $\mu \mathrm{g} / \mathrm{ml}$ hydrocortisone (Sigma), $20 \mathrm{ng} / \mathrm{ml}$ human epidermal growth factor (Life Technologies), $10 \mu \mathrm{g}$ / $\mathrm{ml}$ bovine insulin (Sigma), $100 \mathrm{ng} / \mathrm{ml}$ Toxin from Vibrio cholerae (Sigma) and $50 \mathrm{mM}$ HEPES GIBCO. All culture media were supplemented with $2 \mathrm{mM}$ L-glutamine GIBCO and $1 \%$ penicillin-streptomycin $\mathrm{GIBCO}^{\circledR}$. For MC10ASNAIL and their MCF10A-Puro ${ }^{\mathrm{R}}$ counterpart, $0.5 \mu \mathrm{g} / \mathrm{ml}$ of Puromycin was also added to maintain the plasmid. Cells were grown at $37^{\circ} \mathrm{C}$ with $5 \% \mathrm{CO}_{2}$.

\section{Treatment with TGF $\beta 1$ and TGF $\beta$ signaling inhibitor}

To induce EMT, cells were treated with 5-10 ng/ml of TGF-ß1 (e-Bioscience or R \& D). Cells were passaged continuously under TGF treatment or treated during 4 days, changing the medium every two days. In some experiments, cells were treated with $0,5 \mu \mathrm{M}$ of the TGFßRI inhibitor A83-01 (Sigma Aldrich) to maintain the epithelial phenotype (control cells) or to improve the MET process after TGF- $\beta$ withdrawal.

\section{Antibodies and lectins}

We used the following antibodies to detect glycoantigens: anti-Le ${ }^{\mathrm{a}}$ (7-LE; 1/100); anti-Le ${ }^{\mathrm{b}}$ (LM-137; 1/10), anti-Le ${ }^{\mathrm{x}}$ (3E1; 1/10; EFS Nantes), anti-Le ${ }^{\mathrm{y}}$ (12-4LE; 1/400), anti-H type 3 (Mbr1; $5 \mu \mathrm{g} / \mathrm{ml}$; Enzo life Science), anti-SLe ${ }^{\mathrm{x}}(\mathrm{KM}-93 ; 10 \mu \mathrm{g} / \mathrm{ml}$; Merck-Millipore, Notthingham, U.K and HECA-452; $250 \mu \mathrm{g} / \mathrm{ml}$; BD Bioscience) and anti-SLe ${ }^{\text {a }}$ 19-9; 1/200). 7-LE, LM-137, 12-4LE and 19-9 antibodies were from J. Bara (Villejuif) and U892 (Nantes). All the above antibodies are mouse monoclonal antibodies except from HECA-452, which was produced in rat. E-Cadherin was detected with 24E10 rabbit monoclonal antibody (1/200; Cell Signaling Technology) and vimentin with IF01 mouse monoclonal antibody $(1 / 20$ for flow cytometry and 1/50 for immunofluorescence; Calbiochem, Merck Millipore). Prolectin was detected with a rabbit polyclonal antibody [16].

We also used several recombinant bacterial lectins (BC2L-A, BC2L-C-Nt, PA-IL, RSL) produced in E. Coli in the CERMAV laboratory (CNRS UPR5301, Grenoble, France) as well as the plant lectin UEA-I (Vector laboratories, Burlingame, CA).

\section{Plasmid construction}

For expression of the CRD from prolectin, a pET$24 \mathrm{a}$-Pro vector was obtained by gene synthesis from GENEART (Life Technologies; Regensburg, Germany). This plasmid drives expression of the CRD of prolectin (residues 247 to 380) with the biotinylation acceptor sequence GLNDIFGAQKIEWHE appended at the C-terminus, as described in [16].

\section{Preparation of biotinylated prolectin tetramers}

A 3 Liters culture of E.Coli strain BL21(D3) transformed with the pET-24a-Pro plasmid was prepared 
and prolectin expression was induced by addition of $1 \mathrm{mM}$ Isopropyl $\beta$-D-1 thiogalactopyranoside (IPTG). After incubation for $5 \mathrm{~h}$ at $37^{\circ} \mathrm{C}$, bacteria were pelleted and resuspended in saccharose buffer before freezing. Bacteria were thawed, sonicated and digested with $300 \mu \mathrm{g} / \mathrm{ml}$ Lyzosyme. Inclusion bodies were washed 8 times with wash buffer $(50 \mathrm{mM}$ Tris- $\mathrm{HCl} \mathrm{pH} 8,100 \mathrm{mM}$ $\mathrm{NaCl}, 0.5 \%$ Triton X-100 + protease inhibitors without EDTA (Roche)), resuspended in $8 \mathrm{M}$ urea for protein denaturation, collected by ultracentrifugation and protein concentration was determined. Inclusion bodies $(8-16 \mathrm{mg})$ were resuspended in $125 \mathrm{ml}$ of renaturation buffer (100 mM Tris- $\mathrm{HCl} \mathrm{pH}$ 8, $25 \mathrm{mM} \mathrm{CaCl}$, 0.5 M NDSB256 (Sigma), $5 \mathrm{mM}$ reduced glutathione, $0.5 \mathrm{mM}$ oxydized glutathione + protease inhibitors without EDTA (Roche)) and incubated for 3 days at $4^{\circ} \mathrm{C}$ under slow agitation. The renatured protein was concentrated on filters with $1-3 \mathrm{kDa}$ cut-off (Amicon) and biotinylated by incubation with the BirA enzyme for $5 \mathrm{~h}$. The biotinylated protein was applied on a HiLoad S200 gel filtration column (GE Healthcare). Elution was performed in phosphate buffer saline (PBS) and fractions corresponding to the monomer of prolectin were pooled, aliquoted and stored at $-80^{\circ} \mathrm{C}$.

Since lectins affinity for glycosylated ligands is generally improved when they are in multimeric states, we formed tetramers of prolectin by taking advantage of the property of the streptavidin molecule to have 4 biotin-binding sites. Biotinylated-prolectin monomers were incubated with streptavidin-horseradish peroxidase (strepatvidin-HRP; Vector laboratories, Burlingame, $\mathrm{CA}$ ) or streptavidin-phycoerythrin (streptavidin-PE; BD Pharmingen) at a molar ratio of 1:5 in TBS-BSA, $10 \mathrm{mM}$ $\mathrm{CaCl}_{2}$ for $1-2 \mathrm{~h}$ at room temperature. Tris-buffered saline (TBS) was used instead of PBS to avoid the formation of calcium phosphate precipitates. These tetramers were then used in the different assays described below.

\section{Enzyme linked lectin assay}

Oligosaccharides conjugated to polyacrylamide beads (PAA) were obtained from N. Bovin (Shemyakin Institute of Bioorganic Chemistry, Moscow, Russia). Human serum albumin (HSA) conjugated with oligosaccharides were purchased from Isosep (Tullinge, Sweden). Detailed formulas of the oligosaccharides are given in Table S3.

Synthetic oligosaccharides were used at $0.1 \mathrm{mg} / \mathrm{ml}$. All samples were diluted in coating buffer (CarbonateBicarbonate $0.1 \mathrm{M} \mathrm{pH} \mathrm{9.5)} \mathrm{and} \mathrm{adsorbed} \mathrm{in} \mathrm{duplicates}$ on "Maxisorb" 96 well- plates (Nunc, ThermoFisher Scientific, Waltman, MA) with overnight incubation at $37^{\circ} \mathrm{C}$. After 3 washes with PBS- $0.05 \%$ Tween 20 (PBS-T), blocking of the non-specific protein binding sites was performed with PBS-5\% BSA for $1 \mathrm{~h}$ at $37^{\circ} \mathrm{C}$. Biotinylated BC2L-C-Nt diluted to $1 \mu \mathrm{g} / \mathrm{ml}$ in TBS-1\% BSA, $10 \mathrm{mM}$ $\mathrm{CaCl}_{2}$ was added to the plate for $2 \mathrm{~h}$ at room temperature. After 3 washes with PBS-T, streptavidin-HRP at $5 \mu \mathrm{g} / \mathrm{ml}$ in PBS-1\% BSA (in the wells incubated with BC2L-C-Nt) or $4 \mu \mathrm{g} / \mathrm{ml}$ of prolectin tetramerized with streptavidinHRP in TBS- $1 \%$ BSA, $10 \mathrm{mM} \mathrm{CaCl}_{2}$ (see above) were added to the plate, followed by $2 \mathrm{~h}$ incubation at room temperature. After 3 washes with PBS-T, plates were developed by adding $200 \mu \mathrm{l} /$ well of OptEIA substrate $\left(3,3^{\prime}, 5,5^{\prime}\right.$ tetramethylbenzidine, $\left.\mathrm{BD}\right)$. The reaction was stopped by adding $50 \mu \mathrm{l} /$ well of $1 \mathrm{M}$ phosphoric acid and optical density was read on a iMark Microplate Reader (Bio-Rad).

\section{Flow cytometry}

Cells were trypsinized, aliquoted and resuspended in PBS- $0.1 \%$ BSA (PBS-BSA). After $1-2 \mathrm{~h}$ incubation at $4^{\circ} \mathrm{C}$ with biotinylated lectins diluted in PBS-BSA, cells were washed 3 times with PBS-BSA and incubated with streptavidin-PE (BD Pharmingen) for $30 \mathrm{mn}$ at $4^{\circ} \mathrm{C}$. Alternatively cells were incubated directly with $10 \mu \mathrm{g} / \mathrm{ml}$ prolectin in complex with streptavidin-PE in TBS-0.1\% BSA, $10 \mathrm{mM} \mathrm{CaCl} 2$ (or $2.5 \mathrm{mM}$ EDTA for the negative control) for $1-2 \mathrm{~h}$ at $4^{\circ} \mathrm{C}$.

For detection of the glycosylated antigens, cells were incubated with primary antibodies diluted in PBS-BSA for at least $30 \mathrm{mn}$ at $4^{\circ} \mathrm{C}$. After washes with PBS-BSA, the cells were incubated with Goat $\mathrm{F}(\mathrm{ab})_{2}$ anti-mouse $\operatorname{IgG}(\mathrm{H}+\mathrm{L})$-FITC (Beckman) or Goat anti-rat $\operatorname{IgG}(\mathrm{H}+\mathrm{L}$ )-FITC (Novex, Life Technologies) $1 / 200$ in PBS-BSA for $30 \mathrm{mn}$ at $4^{\circ} \mathrm{C}$.

In all cases, cells were washed 3 times with PBS, resuspended in PBS and analyzed on a FACSCalibur flow cytometer (BD).

\section{Immunofluorescence}

Cells were fixed with paraformaldehyde $4 \%$ in PBS for $20 \mathrm{mn}$ at room temperature. Blocking and permeabilization were then performed simultaneously using PBS- $0.1 \%$ Triton X-100-10\% FCS. Cells were incubated sequentially with anti-E-Cadherin and antiVimentin (see above) diluted in PBS-10\% FCS for $1 \mathrm{~h}$ at room temperature. After washes with PBS- $10 \%$ FCS, cells were incubated with Goat anti-rabbit $\operatorname{IgG}(\mathrm{H}+\mathrm{L})$ DyLight 488 (KPL), 1/400 and then with Goat anti-mouse $\operatorname{IgG}(\mathrm{H}+\mathrm{L})$-Rhodamin (Chemicon, Merck Millipore), 1/200 and NucBlue Live Stain (Molecular Probes, Life Technologies). After washes with PBS, slides were mounted in ProLong Gold anti-fade reagent (Molecular Probes, Life Technologies).

\section{Tissue sections}

Ethanol-fixed colorectal tumor sections were obtained after cancer surgery. They were collected before the French law 88-138 of December 20, 1988 concerning resection of human tissues after death for scientific 
investigations. The samples were obtained from the Nantes University Hospital Center for Biological Resources (http://relib.fr), under the Cancerology program approved by the ministry of research (approval DC-2011-1399). A breast tumor tissue microarray (TMA; formalin-fixed; 40 tumors, 10 paired lymph node metastasis and 10 paired adjacent "normal" tissue), a lung tumor TMA (formalinfixed; 40 tumors, 7 paired lymph node metastasis, 2 paired bone metastasis, 1 paired soft tissue metastasis and 10 paired adjacent "normal" tissue) as well as a uterine cervix tumor TMA (formalin-fixed; 40 tumors, 5 paired lymph node metastasis and 5 paired adjacent "normal" tissue) were bought from SuperBiochips Laboratories Ltd (Seoul, South Korea). The company certifies that the "human material has been removed or collected with the donor's prior consent and that no payment whatsoever has been made to the latter".

\section{Histochemistry}

The tissue sections were deparaffinized, then endogenous peroxidases were blocked by $20 \mathrm{~min}$ incubation in PBS- $0.3 \%$ Hydrogen peroxide. Non-specific binding was blocked by 60 min incubation in PBS-5\% BSA. Prolectin-Streptavidin HRP tetramers in TBS-1\% BSA$10 \mathrm{mM} \mathrm{CaCl} 2$ were added for $2 \mathrm{~h}$ at room temperature. After 3 washes with PBS, peroxidase substrate (AEC kit, Vector Laboratories) was added to the slide for 10-20 min followed by quick soaking in Mayer's hematoxyllin solution (Vector Laboratories) for contrast staining.

Slides were imaged with a Nanozoomer slide scanner (Hamamatsu, Hamamatsu City, Japan).

\section{Adhesion assay under flow}

Microfluidic experiments were performed using the BioFlux system (Fluxion) in a 48 -well plate format.

BioFlux ${ }^{\circledR}$ microchannels were coated with tetramers of prolectin-streptavidin $(100 \mu \mathrm{g} / \mathrm{ml})$ in coating buffer (carbonate-bicarbonate $0.1 \mathrm{M} \mathrm{pH} 9.5$ ) containing $0.5 \mathrm{mM}$ $\mathrm{CaCl} 2$, overnight at $37^{\circ} \mathrm{C}$. Cells were trypsinized, counted and resuspended at $5 \times 10^{6}$ cells $/ \mathrm{ml}$ in PBS containing $\mathrm{Ca}^{2+}$ and $\mathrm{Mg}^{2+}$ and $5 \%$ FCS. $25 \mathrm{mM}$ of D (+)-Galactose (Sigma) or L-(-)-Fucose (Sigma) were added at final concentrations of $25 \mathrm{mM}$ as indicated in Figure legends. The cell suspension was loaded in the entry well of the BioFlux plate and a shear flow of 0.05-0.1 Dyn $/ \mathrm{cm}^{2}$ was applied by the BioFlux pump, to inject the cells into the microchannel. A Series of 600 pictures, corresponding to 60-second films were recorded with a Leica DMI 6000B microscope. After the video acquisition, microchannels were washed 10 min with PBS containing $\mathrm{Ca}^{2+}, \mathrm{Mg}^{2+}$ at 4 Dyn $/ \mathrm{cm}^{2}$ in order to remove unbound cells and pictures of the cells attached along the whole channels were taken.

In some cases cells were detached by flushing with PBS- $0.02 \%$ EDTA and trypsin and stained with prolectin for fluorescence or flow cytometry analysis. Video data were analyzed by chronophotography on 10 pictures segments, using the Fiji software (http://fiji.sc).

\section{qRT-PCR}

RNA extractions were performed using the Nucleospin RNA II purification kit (Macherey Nagel) following instructions of the manufacturer. RNA concentration was measured using a Nanodrop (Thermo Fisher Scientific) instrument. Reverse transcription was performed on $0.5-1 \mu \mathrm{g}$ of total RNA with oligo-dT and the Superscript II reverse transcriptase (Life Technologies) as recommended by the manufacturer with 1-2 $\mu$ l of the cDNAs used for the qPCR step.

For FUT1 and FUT3, the Taqman Universal PCR Mastermix (Applied Biosystems, Life Technologies) was used with the primers and probes described by Nyström et al ([53], See Table S1). GAPDH was used for normalization using Taqman Pre-developped Assay Reagents primers and probe mix (Applied Biosystems, Life Technologies). For CDH1 and B-Actin, qPCR was performed using the Brilliant II SyBrGreen Mastermix (Agilent) and primers indicated in Table S2. qPCRs reactions were ran on a Mx3500P qPCR machine (Agilent). For normalization of the $\mathrm{qPCR}$ results, the $\Delta \Delta \mathrm{CT}$ method was applied.

\section{ACKNOWLEDGMENTS}

The authors are grateful to the CHEM-Symbiose core facility of the University of Nantes for synthesis of 2F-Fuc, as well as the Flow cytometry (Cytocell) Core Facility and to the Cell and Tissue Imaging (MicroPiCell) Core Facility of the Nantes University for their valuable technical assistance.

CHO-Le ${ }^{a}$ and $\mathrm{CHO}-\mathrm{Le}^{\mathrm{b}}$ cell lines were a kind gift from Pr Jan Holgersson (University of Gothenburg, Gothenburg, Sweden). MCF10A-Kras(v12) and MCF10ASNAIL were kind gifts of Dr Ben Ho Park and Dr Stephane Ansieau, respectively.

The authors also would like to thank Elsa Mével, Elodie Munier, Grâce Ada Da Silva and Thomas Harbonnier who participated to the project during their master training periods as well as Dr Kristina Nyström, Dr Philippe Juin and all the members of the team 5 of U892 for helpful discussions.

\section{Abbreviations}

HBGA: Histo-Blood Group Antigen, EMT: epithelial-to-mesenchymal transition, MET: mesenchymalto-epithelial transition, Le ${ }^{\mathrm{a}}$ : Lewis A, Le ${ }^{\mathrm{b}}$ : Lewis B, Le ${ }^{\mathrm{x}}$ : Lewis X, Le ${ }^{\mathrm{y}}$ : Lewis Y, SLe ${ }^{\mathrm{x}}$ : Sialyl-Lewis X, SLe ${ }^{\mathrm{a}}$ : SialylLewis A; CSC: cancer stem cell, ES: embryonic stem cell, iPS: induced pluripotent stem cell, CRD: carbodhydrate recognition domain, FUT: fucosyltransferase, TGF-ß: transforming growth factor $\beta$, HSA: human serum albumin, 
PAA: polyacrylamide; KFN: kifunensine; MFI: mean fluorescence intensity; $\mathrm{CHO}$ : Chinese hamster ovary; FCS: fetal calf serum; PBS: phosphate-buffered saline; TBS: Tris-buffered saline; HRP: horseradish peroxidase; TMA: tissue microarray

\section{GRANT SUPPORT}

This work was supported by Inserm, CNRS and the Ligue Nationale Contre le Cancer. The authors also acknowledge the ANR grant NeoLect (ANR-11-BSV5-002).

\section{CONFLICTS OF INTEREST}

The authors declare that they have no conflicts of interest.

\section{REFERENCES}

1. Boligan KF, Mesa C, Fernandez LE, von Gunten S. Cancer intelligence acquired (CIA): tumor glycosylation and sialylation codes dismantling antitumor defense. Cellular and molecular life sciences: CMLS. 2015;72:1231-48. doi: 10.1007/s00018-014-1799-5.

2. Ghazarian H, Idoni B, Oppenheimer SB. A glycobiology review: carbohydrates, lectins and implications in cancer therapeutics. Acta Histochem. 2011; 113:236-247.

3. Julien S, Ivetic A, Grigoriadis A, Qize D, Burford B, Sproviero D, Picco G, Gillett C, Papp SL, Schaffer L, Tutt A, Taylor-Papadimitriou J, Pinder SE, et al. Selectin Ligand Sialyl-Lewis $\mathrm{x}$ Antigen Drives Metastasis of Hormone-Dependent Breast Cancers. Cancer Res. 2011; 71:7683-93. doi: 10.1158/0008-5472.CAN-11-1139.

4. Konno A, Hoshino Y, Terashima S, Motoki R, Kawaguchi T. Carbohydrate expression profile of colorectal cancer cells is relevant to metastatic pattern and prognosis. Clin Exp Metastasis. 2002; 19:61-70.

5. Rambaruth ND, Dwek MV. Cell surface glycan-lectin interactions in tumor metastasis. Acta Histochem. 2011; 113:591-600.

6. Foroni C, Broggini M, Generali D, Damia G. Epithelialmesenchymal transition and breast cancer: role, molecular mechanisms and clinical impact. Cancer Treat Rev. 2012; 38:689-697.

7. Sharon N, Lis H. Lectin biochemistry. New way of protein maturation. Nature. 1986; 323:203-204.

8. Leathem AJ, Brooks SA. Predictive value of lectin binding on breast-cancer recurrence and survival. Lancet. 1987; 1:1054-1056.

9. Audfray A, Beldjoudi M, Breiman A, Hurbin A, Boos I, Unverzagt C, Bouras M, Lantuejoul S, Coll JL, Varrot A, Le Pendu J, Busser B, Imberty A. A recombinant fungal lectin for labeling truncated glycans on human cancer cells. PLoS One. 2015; 10:e0128190.
10. Blanchard B, Nurisso A, Hollville E, Tetaud C, Wiels J, Pokorna M, Wimmerova M, Varrot A, Imberty A. Structural basis of the preferential binding for globo-series glycosphingolipids displayed by Pseudomonas aeruginosa lectin I. J Mol Biol. 2008; 383:837-853.

11. Lameignere E, Malinovska L, Slavikova M, Duchaud E, Mitchell EP, Varrot A, Sedo O, Imberty A, Wimmerova M. Structural basis for mannose recognition by a lectin from opportunistic bacteria Burkholderia cenocepacia. Biochem J. 2008; 411:307-318.

12. Kostlanova N, Mitchell EP, Lortat-Jacob H, Oscarson S, Lahmann M, Gilboa-Garber N, Chambat G, Wimmerova M, Imberty A. The fucose-binding lectin from Ralstonia solanacearum. A new type of beta-propeller architecture formed by oligomerization and interacting with fucoside, fucosyllactose, and plant xyloglucan. J Biol Chem. 2005; 280:27839-27849.

13. Sulak O, Cioci G, Delia M, Lahmann M, Varrot A, Imberty A, Wimmerova M. A TNF-like trimeric lectin domain from Burkholderia cenocepacia with specificity for fucosylated human histo-blood group antigens. Structure. 2010; 18:59-72.

14. Sulak O, Cioci G, Lameignere E, Balloy V, Round A, Gutsche I, Malinovska L, Chignard M, Kosma P, Aubert DF, Marolda CL, Valvano MA, Wimmerova M, et al. Burkholderia cenocepacia BC2L-C is a super lectin with dual specificity and proinflammatory activity. PLoS Pathog. 2011; 7:e1002238.

15. Dam TK, Brewer CF. Lectins as pattern recognition molecules: the effects of epitope density in innate immunity. Glycobiology. 2010; 20:270-279.

16. Graham SA, Jegouzo SA, Yan S, Powlesland AS, Brady JP, Taylor ME, Drickamer K. Prolectin, a glycan-binding receptor on dividing $\mathrm{B}$ cells in germinal centers. J Biol Chem. 2009; 284:18537-18544.

17. Kobzdej MM, Leppänen A, Ramachandran V, Cummings RD, McEver RP. Discordant expression of selectin ligands and sialyl Lewis x-related epitopes on murine myeloid cells. Blood. 2002; 100:4485-4494.

18. Hoeflich KP, O'Brien C, Boyd Z, Cavet G, Guerrero S, Jung K, Januario T, Savage H, Punnoose E, Truong T, Zhou W, Berry L, Murray L, et al. In vivo antitumor activity of MEK and phosphatidylinositol 3-kinase inhibitors in basal-like breast cancer models. Clin Cancer Res. 2009; 15:4649-4664.

19. Kao J, Salari K, Bocanegra M, Choi YL, Girard L, Gandhi J, Kwei KA, Hernandez-Boussard T, Wang P, Gazdar AF, Minna JD, Pollack JR. Molecular profiling of breast cancer cell lines defines relevant tumor models and provides a resource for cancer gene discovery. PLoS One. 2009; 4:e6146.

20. Neve RM, Chin K, Fridlyand J, Yeh J, Baehner FL, Fevr T, Clark L, Bayani N, Coppe JP, Tong F, Speed T, Spellman PT, DeVries S, et al. A collection of breast cancer 
cell lines for the study of functionally distinct cancer subtypes. Cancer Cell. 2006; 10:515-527.

21. de Vries T, Knegtel RM, Holmes EH, Macher BA. Fucosyltransferases: structure/function studies. Glycobiology. 2001; 11:119R-128R.

22. Comijn J, Berx G, Vermassen P, Verschueren K, van Grunsven L, Bruyneel E, Mareel M, Huylebroeck D, van Roy F. The two-handed $\mathrm{E}$ box binding zinc finger protein SIP1 downregulates E-cadherin and induces invasion. Mol Cell. 2001; 7:1267-1278.

23. Remacle JE, Kraft H, Lerchner W, Wuytens G, Collart C, Verschueren K, Smith JC, Huylebroeck D. New mode of DNA binding of multi-zinc finger transcription factors: deltaEF1 family members bind with two hands to two target sites. EMBO J. 1999; 18:5073-5084.

24. Jezequel P, Campone M, Gouraud W, Guerin-Charbonnel C, Leux C, Ricolleau G, Campion L. bc-GenExMiner: an easy-to-use online platform for gene prognostic analyses in breast cancer. Breast Cancer Res Treat. 2012; 131:765-775.

25. Gyorffy B, Lanczky A, Eklund AC, Denkert C, Budczies J, Li Q, Szallasi Z. An online survival analysis tool to rapidly assess the effect of 22,277 genes on breast cancer prognosis using microarray data of 1,809 patients. Breast Cancer Res Treat. 2010; 123:725-731.

26. Esmaeilsabzali H, Beischlag TV, Cox ME, Parameswaran AM, Park EJ. Detection and isolation of circulating tumor cells: principles and methods. Biotechnol Adv. 2013; 31:1063-1084.

27. Onuma Y, Tateno H, Hirabayashi J, Ito Y, Asashima M. rBC2LCN, a new probe for live cell imaging of human pluripotent stem cells. Biochem Biophys Res Commun. 2013; 431:524-529.

28. Tateno H, Onuma Y, Ito Y. Live-cell imaging of human pluripotent stem cells by a novel lectin probe rBC2LCN. Methods Mol Biol. 2014; 1200:313-318.

29. Lamouille S, Xu J, Derynck R. Molecular mechanisms of epithelial-mesenchymal transition. Nat Rev Mol Cell Biol. 2014; 15:178-196.

30. Aigner K, Dampier B, Descovich L, Mikula M, Sultan A, Schreiber M, Mikulits W, Brabletz T, Strand D, Obrist P, Sommergruber W, Schweifer N, Wernitznig A, et al. The transcription factor ZEB1 (deltaEF1) promotes tumour cell dedifferentiation by repressing master regulators of epithelial polarity. Oncogene. 2007; 26:6979-6988.

31. Eger A, Aigner K, Sonderegger S, Dampier B, Oehler S, Schreiber M, Berx G, Cano A, Beug H, Foisner R. DeltaEF1 is a transcriptional repressor of E-cadherin and regulates epithelial plasticity in breast cancer cells. Oncogene. 2005; 24:2375-2385.

32. Kim RK, Suh Y, Yoo KC, Cui YH, Kim H, Kim MJ, Gyu Kim I, Lee SJ. Activation of KRAS promotes the mesenchymal features of basal-type breast cancer. Exp Mol Med. 2015; 47:e137.

33. Zhang J, Tian X-J, Zhang H, Teng Y, Li R, Bai F, Elankumaran S, Xing J. TGF-ß-induced epithelial-to- mesenchymal transition proceeds through stepwise activation of multiple feedback loops. Science signaling. 2014; 7.

34. Sakuma K, Aoki M, Kannagi R. Transcription factors c-Myc and CDX2 mediate E-selectin ligand expression in colon cancer cells undergoing EGF/bFGF-induced epithelialmesenchymal transition. Proc Natl Acad Sci U S A. 2012; 109:7776-7781.

35. Tan Z, Lu W, Li X, Yang G, Guo J, Yu H, Li Z, Guan F. Altered N-Glycan Expression Profile in Epithelial-toMesenchymal Transition of NMuMG Cells Revealed by an Integrated Strategy Using Mass Spectrometry and Glycogene and Lectin Microarray Analysis. J Proteome Res. 2014; 13:2783-2795.

36. Barthel SR, Hays DL, Yazawa EM, Opperman M, Walley KC, Nimrichter L, Burdick MM, Gillard BM, Moser MT, Pantel K, Foster BA, Pienta KJ, Dimitroff CJ. Definition of molecular determinants of prostate cancer cell bone extravasation. Cancer Res. 2013; 73:942-952.

37. Jorgensen T, Berner A, Kaalhus O, Tveter KJ, Danielsen HE, Bryne M. Up-regulation of the oligosaccharide sialyl LewisX: a new prognostic parameter in metastatic prostate cancer. Cancer Res. 1995; 55:1817-1819.

38. Kannagi R, Izawa M, Koike T, Miyazaki K, Kimura N. Carbohydrate-mediated cell adhesion in cancer metastasis and angiogenesis. Cancer Sci. 2004; 95:377-384.

39. Ogawa J, Sano A, Koide S, Shohtsu A. Relation between recurrence and expression of proliferating cell nuclear antigen, sialyl LewisX, and sialyl Lewis(a) in lung cancer. J Thorac Cardiovasc Surg. 1994; 108:329-336.

40. Sawada R, Tsuboi S, Fukuda M. Differential E-selectindependent adhesion efficiency in sublines of a human colon cancer exhibiting distinct metastatic potentials. J Biol Chem. 1994; 269:1425-1431.

41. Mejias-Luque R, Lopez-Ferrer A, Garrido M, Fabra A, de Bolos C. Changes in the invasive and metastatic capacities of HT-29/M3 cells induced by the expression of fucosyltransferase 1. Cancer Sci. 2007; 98:1000-1005.

42. Shirure VS, Liu T, Delgadillo LF, Cuckler CM, Tees DF, Benencia F, Goetz DJ, Burdick MM. CD44 variant isoforms expressed by breast cancer cells are functional E-selectin ligands under flow conditions. American journal of physiology Cell physiology. 2015; 308:C68-78. doi: 10.1152/ajpcell.00094.2014.

43. Hotta H, Hamamura K, Yamashita K, Shibuya H, Tokuda N, Hashimoto N, Furukawa K, Yamamoto N, Hattori $\mathrm{H}$, Toyokuni S, Ueda M. Lewis y antigen is expressed in oral squamous cell carcinoma cell lines and tissues, but disappears in the invasive regions leading to the enhanced malignant properties irrespective of sialyl-Lewis x. Glycoconj J. 2013; 30:585-597.

44. Lin W-L, Lin Y-S, Shi G-Y, Chang C-F, Wu H-L. Lewisy Promotes Migration of Oral Cancer Cells by Glycosylation of Epidermal Growth Factor Receptor. PLoS One. 2015; 10.

45. Lu YC, Chen CN, Chu CY, Lu J, Wang BJ, Chen CH, Huang MC, Lin TH, Pan CC, Chen SS, Hsu WM, Liao YF, 
Wu PY, et al. Calreticulin activates betal integrin via fucosylation by fucosyltransferase 1 in J82 human bladder cancer cells. Biochem J. 2014; 460:69-78.

46. Reticker-Flynn NE, Bhatia SN. Aberrant Glycosylation Promotes Lung Cancer Metastasis through Adhesion to Galectins in the Metastatic Niche. Cancer Discov. 2015; 5:168-181.

47. Fischer KR, Durrans A, Lee S, Sheng J, Li F, Wong ST, Choi H, El Rayes T, Ryu S, Troeger J, Schwabe RF, Vahdat LT, Altorki NK, et al. Epithelial-to-mesenchymal transition is not required for lung metastasis but contributes to chemoresistance. Nature. 2015; 527:472-476.

48. Zheng X, Carstens JL, Kim J, Scheible M, Kaye J, Sugimoto H, Wu C-C, LeBleu VS, Kalluri R. Epithelialto-mesenchymal transition is dispensable for metastasis but induces chemoresistance in pancreatic cancer. Nature. 2015; 527:525-530.

49. Marionneau S, Ruvoen N, Le Moullac-Vaidye B, Clement M, Cailleau-Thomas A, Ruiz-Palacois G, Huang P, Jiang X, Le Pendu J. Norwalk virus binds to histo-blood group antigens present on gastroduodenal epithelial cells of secretor individuals. Gastroenterology. 2002; 122:1967-1977.
50. Löfling J, Diswall M, Eriksson S, Boren T, Breimer M, Holgersson J. Studies of Lewis antigens and H. pylori adhesion in $\mathrm{CHO}$ cell lines engineered to express Lewis b determinants. Glycobiology. 2008; 18:494-501.

51. Konishi H, Karakas B, Abukhdeir AM, Lauring J, Gustin JP, Garay JP, Konishi Y, Gallmeier E, Bachman KE, Park B. Knock-in of Mutant K-ras in Nontumorigenic Human Epithelial Cells as a New Model for Studying K-ras, ÄìMediated Transformation. Cancer research. 2007; 67:8460-8467.

52. Gras B, Jacqueroud L, Wierinckx A, Lamblot C, Fauvet Fdr, Lachuer Jl, Puisieux A, Ansieau Sp. Snail Family Members Unequally Trigger EMT and Thereby Differ in Their Ability to Promote the Neoplastic Transformation of Mammary Epithelial Cells. PLoS One. 2014; 9.

53. Nystrom K, Grahn A, Lindh M, Brytting M, Mandel U, Larson G, Olofsson O. Virus-induced transcriptional activation of host FUT genes associated with neoexpression of Ley in cytomegalovirus-infected and sialylLex in varicella-zoster virus-infected diploid human cells. Glycobiology. 2007; 17:355-366. 